Portland State University

PDXScholar

$11-2-1992$

\title{
Cytogenetics of Delphinium (Ranunculaceae) Species Native to Oregon
}

Jill Yeatman Turner

Portland State University

Follow this and additional works at: https://pdxscholar.library.pdx.edu/open_access_etds

Part of the Biology Commons

Let us know how access to this document benefits you.

\section{Recommended Citation}

Turner, Jill Yeatman, "Cytogenetics of Delphinium (Ranunculaceae) Species Native to Oregon" (1992). Dissertations and Theses. Paper 4566.

https://doi.org/10.15760/etd.6450

This Thesis is brought to you for free and open access. It has been accepted for inclusion in Dissertations and Theses by an authorized administrator of PDXScholar. Please contact us if we can make this document more accessible: pdxscholar@pdx.edu. 
AN ABSTRACT OF THE THESIS OF JILL YEATMAN TURNER for the Master of Science in Biology presented November 2, 1992.

Title: Cytogenetics of Delphinium (Ranunculaceae) Species Native to Oregon. APPROVED BY THE MEMBERS OF THE THESIS COMMITTEE:

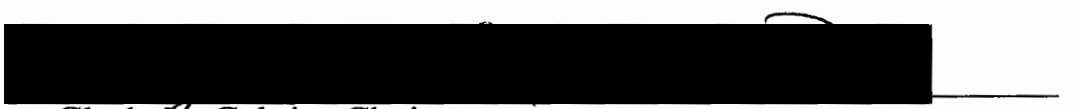

Clyde 4 . Calvin, Chair
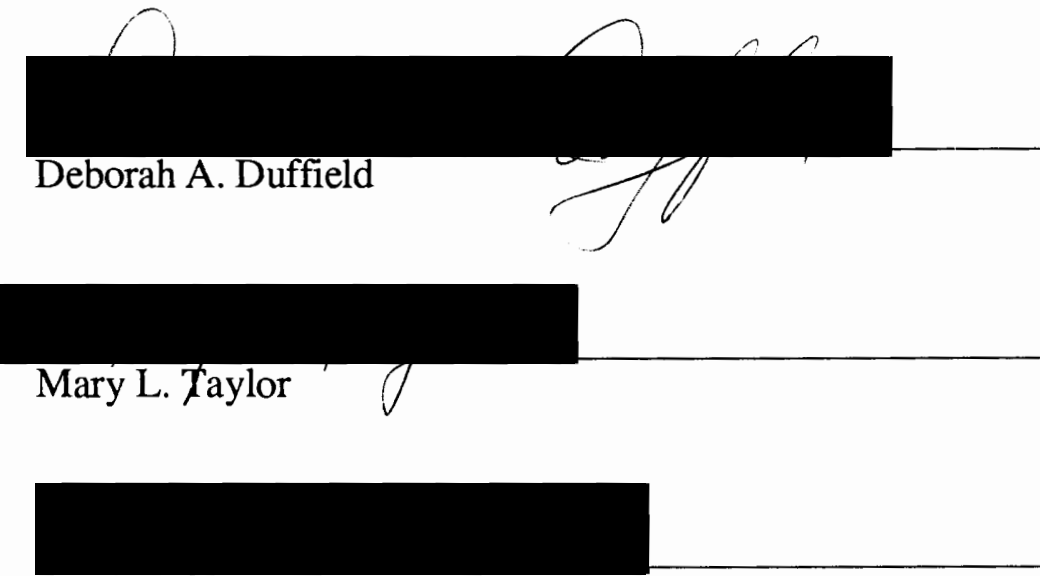

Cord B. Sengstake

Evidence of hybridization, known to occur in the genus Delphinium (Ranunculaceae), has recently been discovered among certain Delphinium species native to Oregon. This issue was investigated by cytogenetic analysis of four native species of Oregon,

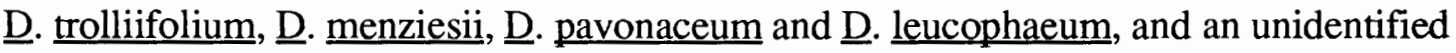
purple delphinium, which is possibly a hybrid. Although many species in this genus are karyotypically similar, any variations found among the karyotypes of these Oregon species might be used to identify parental chromosomes in the purple delphinium (proposed hybrid). Meiotic analysis was used to detect structurally heterozygous homologues that 
are not observable in somatic cells. Reproductive success, an extension of meiosis, was also investigated. In lieu of the endangered status of two of these Oregon species, attempts were made to develop a system for obtaining dividing cells for cytogenetic study that has negligible impact on plant populations.

Apical meristems of seed radicles from the Oregon species and the proposed hybrid were stained with orcein. The metaphase chromosomes were photographed and measured, and chromosome arm ratios and relative lengths calculated. Analyses of variance and multiple comparison tests were run to determine if any significant differences in chromosome measurement exist among these Oregon delphiniums. Satellites and other morphological features were noted. Anther contents were also stained with orcein and microsporogenesis examined. Pollen viability and percent seed germination was determined for each of the species and the proposed hybrid. Callus and organized tissue that developed in vitro were stained with orcein and the mitotic cells examined.

The unbanded karyotypes of the Oregon species and the proposed hybrid are similar in number, size and shape; major structural differences between species, if present, are not observable at this level of chromosome resolution. No markers for the identification of parental chromosomes in the proposed hybrid are available with this staining technique. However, statistical analysis of mean chromosome arm ratio and length indicates that $\underline{D}$. menziesii, $\underline{\mathrm{D}}$. pavonaceum and $\underline{\mathrm{D}}$. leucophaeum are more closely related to one another than they are to $\underline{D}$. trolliifolium and the proposed hybrid, and vice versa. $\underline{\text { D. trolliifolium is }}$ therefore a candidate parent species of the proposed hybrid whereas the other three species are likely not candidates. Karyotypes of these Oregon species are different from those of some species from outside Oregon. This is evidence of chromosome evolution in this genus. The absence of structural heterozygosity in meiotic metaphase I of the proposed hybrid suggests that (1) if it is a hybrid, the genomes of the parent species are structurally similar or (2), recurrent backcrossing with the same parent species may have gradually 
eliminated the chromosomes of the other parent from the hybrid line. High numbers of viable pollen and germinated seeds were found in all the species and the proposed hybrid, evidence that reproductive capacity is not adversely affected by its potentially hybrid condition. Mitosis in tissue culture varies, depending, to a large degree, on cell type. Organized tissues such as roots are sources of more stable karyotypes than calluses, which tend to be mixoploid. The development of plant structures in culture indicates a potential for in vitro plant regeneration. 


\title{
CYTOGENETICS OF DELPHINIUM (RANUNCULACEAE) SPECIES NATIVE TO OREGON
}

by

JLL YEATMAN TURNER

A thesis submitted in partial fulfillment of the requirements for the degree of

\author{
MASTER OF SCIENCE \\ in \\ BIOLOGY
}

Portland State University

1992 
TO THE OFFICE OF GRADUATE STUDIES:

The members of the committee approve the thesis of Jill Yeatman Turner presented November 2, 1992.
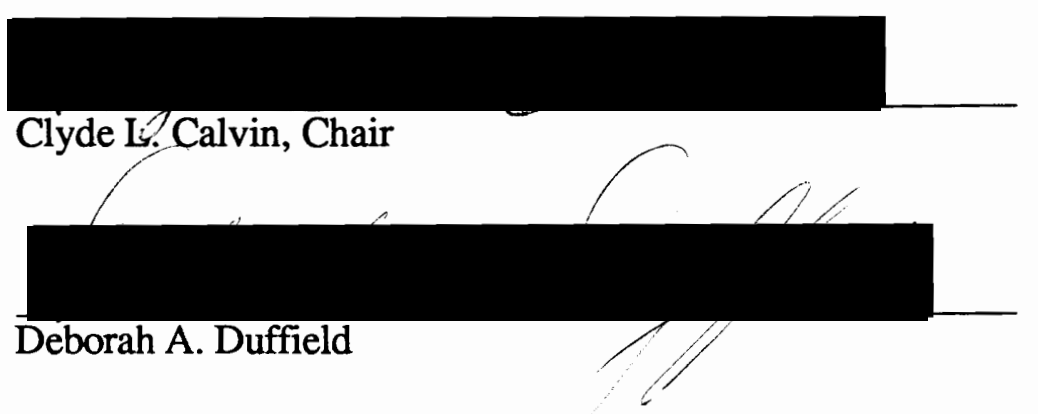

Mary L. Taylor

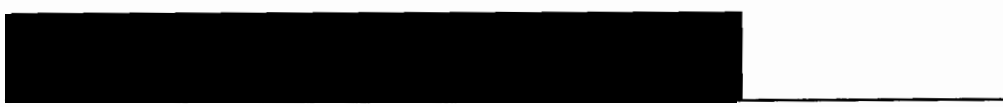

Cord B. Sengstake

\section{APPROVED:}

Richard B. Forbes, Chair, Department of Biology

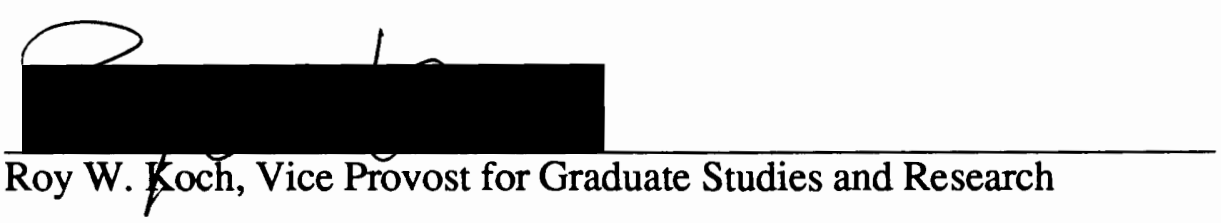




\section{ACKNOWLEDGEMENTS}

First and most foremost, I'd like to thank Dr. Lester Newman for the tremendous amount of time, energy and encouragement he gave me over the course of this study. His expertise in cytogenetics proved useful time and again. Equally, if not more important to this project's success were his steady presence, positive attitude and unending patience.

I'd also like to thank Drs. Clyde Calvin, Debbie Duffield, Cord Sengstake and Mary Taylor for their support and suggestions. Help and encouragement came from fellow students Jeb Bevers, Dave Hayteas, Rosemary Lown, Rick Rausch and Allan Vogel, among others. I thank Dr. Larry Crawshaw, who provided a computer package for statistical analysis, Dr. Randy Zelick, who allowed me to use his laser printer and Dr. Trygve Steen, who helped with the karyotype photographs. The science librarians in the campus library are greatly appreciated for all their help.

Appreciation also goes to Gaylee Goodrich, who kindly showed me where to find delphiniums and shared her knowledge of these species with me. Judith McRae deserves recognition for introducing me to the elusive art of tissue culture, and Peter Chan for all his help in media preparation. Thanks also goes to Dr. Rick Sandstrom for his suggestions and to The Oregon Natural Heritage Foundation for their cooperation.

Thanks for financial support goes to The Hardman Foundation, which contributes to studies relating to the conservation and evolution of native plants of the western United States. 


\section{TABLE OF CONTENTS}

PAGE

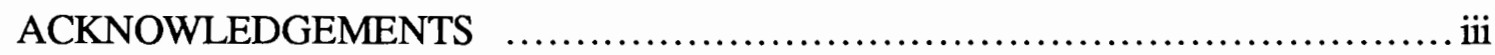

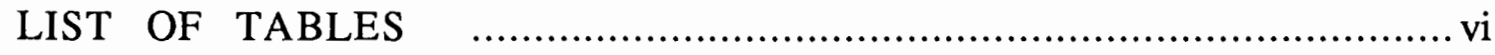

LIST OF FIGURES …............................................................ vii

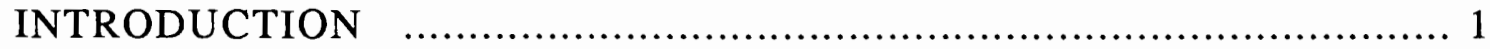

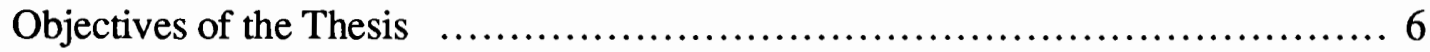

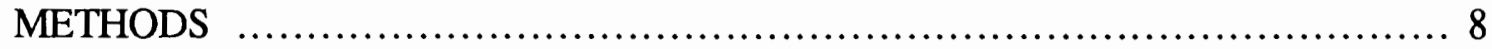

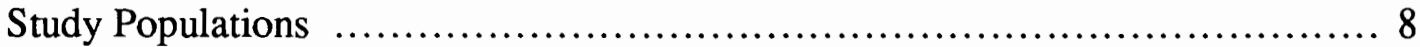

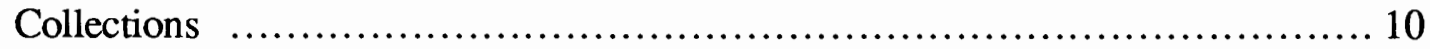

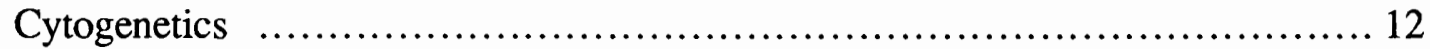

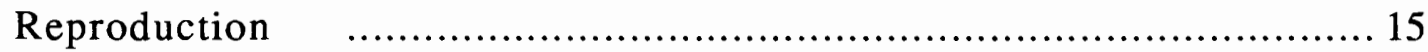

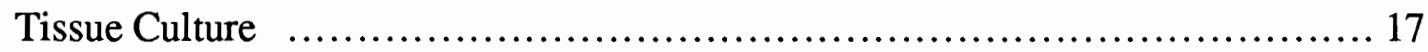

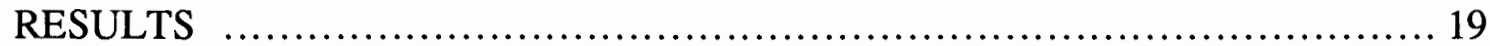

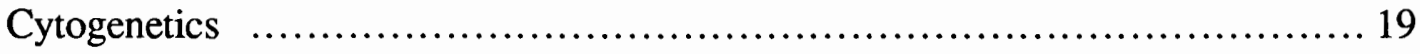

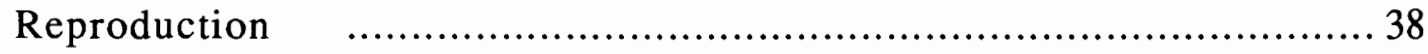

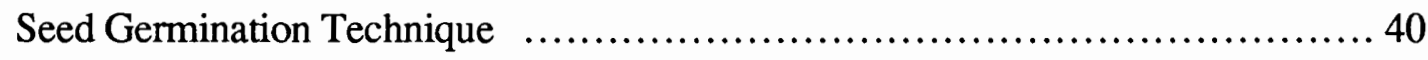

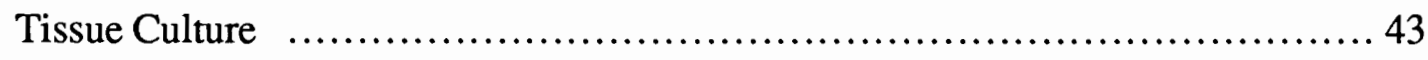

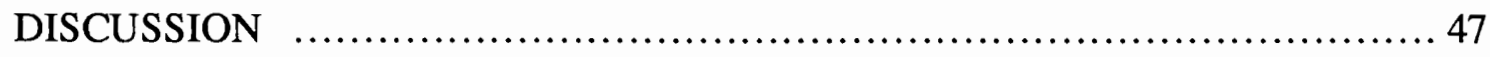

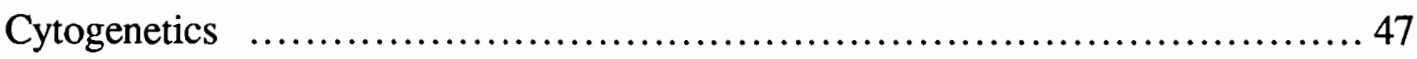

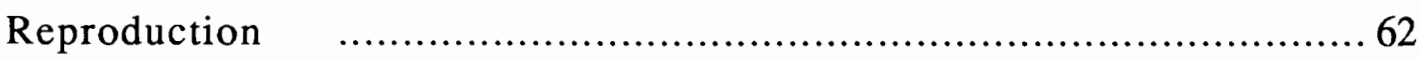

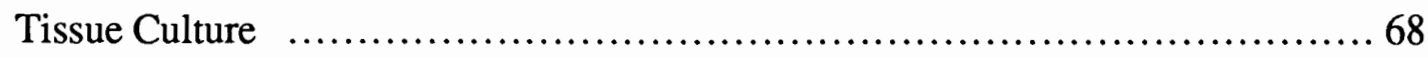

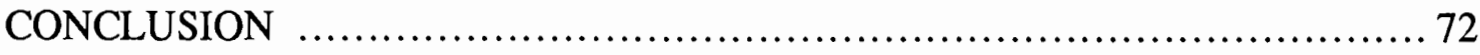




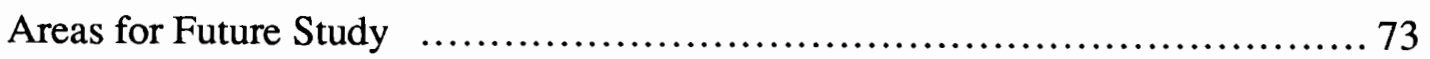

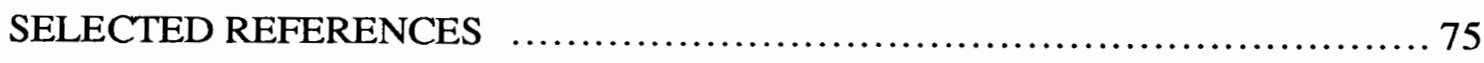

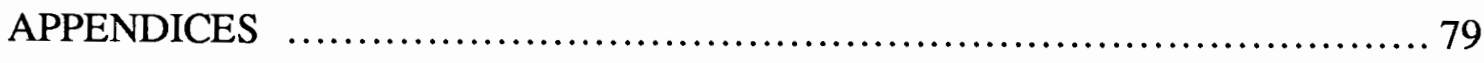

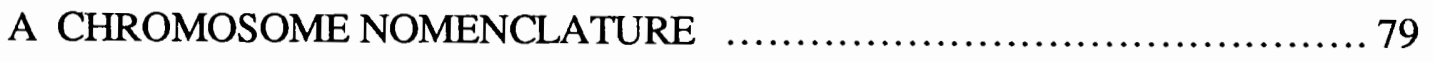

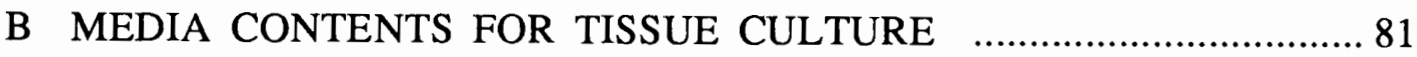

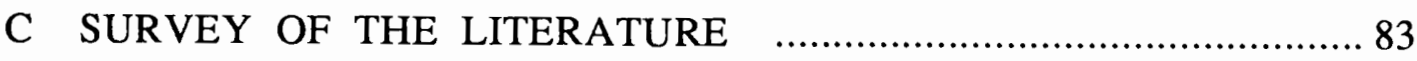




\section{LIST OF TABLES}

TABLE

PAGE

I General Appearance and Distribution of Oregon Delphiniums in This Study .. 5

II Number of Organs and Cells Photographed and/or Scored ................ 14

III Summary of Chromosome Measurements of Oregon Delphiniums ......... 23

IV Minimum Number of Nonhomologous Satellited Chromosomes in a Haploid

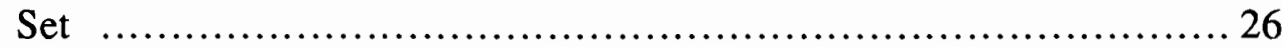

V Pollen Viability in Three Delphinium Populations .......................... 39

VI Seed/Ovule Ratios of Oregon Delphiniums ....................................... 39

VII Percent Seed Germination at $6^{\circ} \mathrm{C}, 12^{\circ} \mathrm{C}$ and Ambient Subfreezing Winter .. 42

VIII Percent Seed Germination at Ambient Subfreezing Winter vs Warm Winter . 42

IX Compare Ploidy in Cultured Callus vs Roots of Three Species with Colchicine Treated and Untreated Samples 45

X Compare Arm Ratios and Relative Lengths Between Oregon and California ....

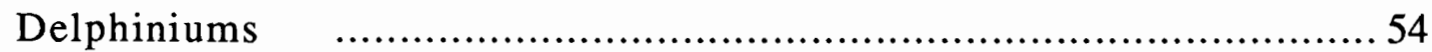

XI Recommended Artificial Conditions for Germinating Delphinium Seeds ... 66 


\section{LIST OF FIGURES}

FIGURE

PAGE

1. Distribution of $\underline{\mathrm{D}}$. leucophaeum and $\underline{\mathrm{D}}$. pavonaceum in Oregon (Hitchcock and Cronquist, 1990)

2. Karytotypes of the purple delphinium, $\underline{\mathrm{D}}$. trolliifolium and

D. menziesii 20

3. Karyotypes of $\underline{D}$. pavonaceum and $\underline{D}$. leucophaeum 21

4. Composite idiogram of Oregon Delphinium species 22

5. Species grouped according to differences in their mean chromosome measurements 25

6. Satellites of $\underline{D}$. pavonaceum and $\underline{D}$. menziesii 27

7. Satellites of the purple delphinium and $\underline{\mathrm{D}}$. leucophaeum 28

8. Satellites of $\underline{D}$. trolliifolium 29

9. Secondary constriction in the purple delphinium and $\underline{\mathrm{D}}$. trolliifolium 31

10. Associated chromosomes in $\underline{\mathrm{D}}$. leucophaeum and $\underline{\mathrm{D}}$. pavonaceum 32

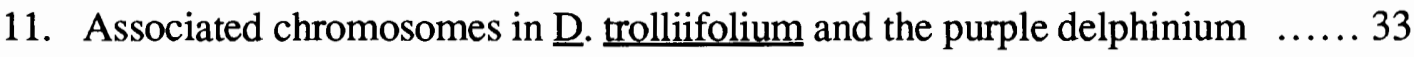

12. Associated chromosomes in $\underline{D}$. menziesii 34

13. Strange set of chromosomes in two cells of one $\underline{\text { D. trolliifolium plant }}$ 35

14. Late metaphase I in $\underline{\mathrm{D}}$. menziesii and $\underline{\mathrm{D}}$. leucophaeum 36

15. Late metaphase I in $\underline{\mathrm{D}}$. trolliifolium, $\underline{\mathrm{D}}$. pavonaceum and the purple delphinium 37

16. Composite idiogram of seven California Delphinium species 53

17. Late metaphase I in $\underline{\mathrm{D}}$. parishii, a California species 58 


\section{INTRODUCTION}

Wild species of the genus Delphinium (Ranunculaceae), commonly known as larkspurs or delphiniums, are herbaceous perennials that are distributed circumboreally in the temperate and mediterranean regions of the world. Of the approximately 300 species that make up this genus (Legro 1961), about 80 are native to North America and most of these grow west of the Mississippi. Twenty-two species are wholly or almost wholly endemic to California and roughly 25 are endemic to the Pacific Northwest (Ewan 1945). A large number of cultivated species and varieties are found worldwide, descendants of a few wild species (Legro 1961).

Associated with plant communities derived during the Tertiary Period (Cenozoic) in both the Old and New Worlds, the genus Delphinium is a widespread, ancient and distinct phylad (Lewis and Epling 1959). Delphiniums are closely related to the genus Aconitum (Ranunculaceae), members of which resemble Delphinium both vegetatively and cytologically (Epling and Lewis 1952).

The zygomorphic flowers that characterize this genus form a raceme. The four petals and five larger sepals may be of contrasting or similar colors ranging in shades from white to lavender, light to dark blue or purple, yellow and red. The upper sepals form a spur, a distinctive feature of this genus and the source of its generic name; the Greek word for delphinium is "delphinion", a diminutive of "delphin" (in reference to the beak shaped sepal spur), their word for dolphin. These perennials become dormant in late summer when the plants die back and only the corms remain viable. Growth begins again the following spring (Epling and Lewis 1952).

A recent taxonomic analysis of several Delphinium species in the Willamette Valley by Goodrich (1985) raises questions regarding their ancestry that might be addressed through 
cytological investigation. Previous cytogenetic studies reveal chromosome homogeneity among members of this genus (Lewis et al. 1951); karyology has not been particularly useful for clarifying relationships. However, with the exception of a brief mention of metaphase I in $\underline{\mathrm{D}}$. trolliifolium (Santana 1975), the chromosomes of species native to Oregon have yet to be examined. The main goal of this project is to describe the mitotic and meiotic chromosomes of four Oregon Delphinium species and a taxonomically unidentified delphinium for comparison within and beyond this group. In addition, a discovery of chromosome markers, such as species specific satellites or variable centromere positions could further contribute to clarification of species relationships.

Enough was known about the reproductive strategies of delphiniums fifty years ago to suggest frequent hybridization and nine putative hybrids were named at that time (Ewan 1945). Since then, more naturally occurring hybrids have been verified (Lewis and Epling 1954) and several more proposed (Warnock 1987). Interspecific hybridization has been shown to lead to the establishment of new species (Lewis and Epling 1959). Possible overlapping blooming periods, unselective pollinators and genetic similarities encourage this phenomenon (Goodrich 1985).

The discovery of a possible hybrid delphinium in Oregon, possibly between D. pavonaceum and a purple flowered species, by Goodrich (1985) raises questions concerning its reproductive capacity and the identification of its parent species. Comparisons of the reproductive potential of this proposed hybrid delphinium to that of established species by meiotic analysis and determination of pollen and seed viability may be of significance. Mitotic chromosome markers could help identify parental chromosomes in the proposed hybrid.

Once widespread throughout western Oregon, delphiniums have retreated with the encroachment of civilization and now exist as scattered populations in habitats ranging from protected natural areas to abandoned hayfields and roadsides. D. pavonaceum and 
D. leucophaeum, which are classified as endangered by the Oregon Natural Heritage Program (1991) are included in this study. Since biological study can affect the reproductive dynamics and general health of a population, another objective is the development of a technique for acquiring and maintaining samples of mitotically active cells that has little or no impact on plant populations.

One such technique that does not impact plant populations is in vitro culture. The history of in vitro culture begins with Schleiden and Schwann, who hypothesized in 1838 that plant cells retained the capacity to regenerate an entire plant. Forty years later Vauchting demonstrated that totipotency worked within genetic limitations. His work led to the successful cultivation of single cells in 1902 by Haberlandt, followed by the culture of conifer embryos by Hanning in 1904. In 1925, the first interspecific hybrid embryo developed into a plant in vitro. Within ten years, White initiated the first long term culture of tomato root tips. The tips eventually survived 28 years and 1600 subcultures (White 1963). Kyte (1987) credits Murashige and Skoog for their discovery in 1948 that cytokinins and auxins play a role in shoot and root regeneration. In 1950, Steward regenerated plants from individual phloem cells of Daucus carota and by 1974, intergeneric fusion of tobacco protoplasts produced hybrid plants (Raven et al. 1986).

The last 15 years have witnessed an explosion in plant tissue culturing. Calluses, organs, embryos and whole plants have been grown in vitro from small fragments, single cells and protoplasts of many species. Plants have been regenerated directly from organized tissues and also indirectly, via a callus stage. Microspores have developed into haploid plants. Apparently, almost any plant species can be cultured if the correct culture conditions are provided (Kyte 1987).

The capacity of plant tissue to continue growth after removal from the plant is an attractive and useful feature to cytogeneticists in that the perpetually dividing cells provide metaphase chromosomes. When a culture of dividing cells is sucessfully maintained, there 
is little need to disturb members of a possibly endangered population for more tissues.

Furthermore, the potential of in vitro culture for regenerating rare and endangered plants for eventual reintroduction into a favorable habitat is apparent.

The protection and revitalization of endangered populations may also be enhanced by the development of a dependable seed germination technique and subsequent seedling development. Tied to this is a better understanding of reproductive potential as reflected by meiotic and developmental processes.

Germinated seed radicles can be a source of mitotic tissue. Mature endospermic Delphinium seeds contain rudimentary embryos which generally require a cold, wet period of one to four months in order to break dormancy prior to germination (Hartmann and Kester 1990). General field observations of several Delphinium species describe a six month period of dormancy broken by winter rains with seedling emergence in early spring (Epling and Lewis 1952).

Separate attempts to initiate seed germination in several Delphinium species have contributed to an understanding of the general requirements for germination but the species vary in the particulars of temperature and timing. These attempts range from exposing potted seeds to ambient winter conditions in their native habitat (Goodrich 1985) to more artificial means such as placement in moist Petri dishes at a constant temperature for a set period of time (Bewley and Black 1985; Santana 1975). Further experimentation is required in order to establish the optimum germination conditions for the Oregon delphiniums of interest here.

This study considers four species: ‥ trolliifolium, D. menziesii, ‥ pavonaceum, D. leucophaeum and one unidentified purple delphinium, all of which can be found in the Willamette Valley. A description by Hitchcock and Cronquist (1990) of approximate size, sepal color and geographical distribution of the four species can be seen in Table I. Included in the table is Goodrich's (1985) assessment of the distribution of the unidentified 
TABLE I

\section{GENERAL APPEARANCE AND DISTRIBUTION OF OREGON DELPHINIUMS IN THIS STUDY}

\begin{tabular}{|c|c|c|c|}
\hline Species & Height & Sepal Color & Geographic Range \\
\hline D. trolliifolium Gray & $7-15 \mathrm{dm}$ & blueish-purple & $\begin{array}{l}\text { western Cascades from } \\
\text { Columbia River Gorge to } \\
\text { northwest California }\end{array}$ \\
\hline D. menziesii D. C. & $<4 \mathrm{dm}$ & purple & $\begin{array}{l}\text { western Cascades from } \\
\text { British Columbia to } \\
\text { northwest California }\end{array}$ \\
\hline D. pavonaceum Ewan & $<5 \mathrm{dm}$ & white & central Willamette Valley \\
\hline D. leucophaeum Greene & $<5 \mathrm{dm}$ & white & $\begin{array}{l}\text { northern Willamette } \\
\text { Valley }\end{array}$ \\
\hline purple delphinium 1 & $<5 \mathrm{dm}^{2}$ & purple & central Willamette Valley \\
\hline
\end{tabular}

1 morphologically similar to $\underline{D}$. pavonaceum (Goodrich 1985)

2 author's observation 
purple delphinium (proposed hybrid). This purple delphinium shall hereafter be referred to as such. For the sake of brevity, when the four established Oregon species and the purple delphinium are discussed collectively, they shall be referred to as "the (five) species". Figure 1 shows the distribution, according to Hitchcock and Cronquist (1990), of the two endemic species in Oregon. The broader distributions of $\underline{\mathrm{D}}$. menziesii and $\underline{\mathrm{D}}$. $\underline{\text { trolliifolium }}$ are not included on the map. Collection sites are also shown.

\section{OBJECTIVES OF THE THESIS}

- Describe the mitotic chromosomes in four Oregon Delphinum species and the purple delphinium. Establish number, size and morphology. Compare karyotypes among these species and with those of Delphinium species reported from elsewhere. Evaluate origin of the purple delphinium.

- Investigate structural and genetic heterogeneity by observations of the first meiotic division, as this has not been described for most members of this genus. Observe microsporogenesis in all groups in the study, with particular focus on the first meiotic division. Relate microsporogenesis to pollen and seed viability.

- Test the reproductive capacity of the purple delphinium, as proper meiosis is required for the establishment of a fertile hybrid. Compare meiosis in this plant with that of established Delphinium species.

- Clarify the overall reproductive potential of the purple delphinium. Investigate the production of viable pollen and seeds and determine germination success in this plant. Gather reproductive information on all four Oregon species for the sake of comparison.

- Devise methods for obtaining meristematic tissues for chromosome studies in order to have little or no effect on the health and population dynamics of plants in the field.

- Attempt plant regeneration via tissue culture and seed germination. 


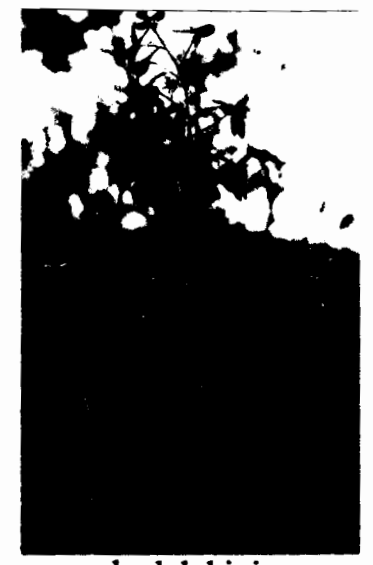

purple delphinium

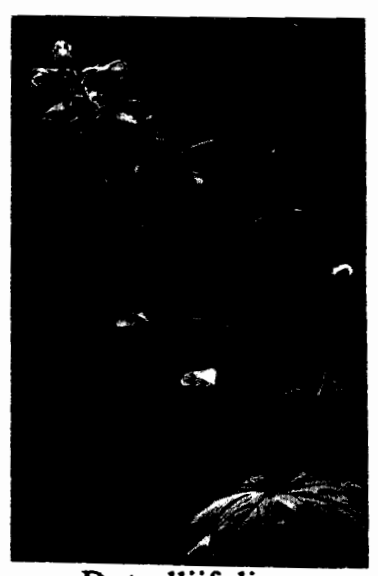

D. trolliifolium

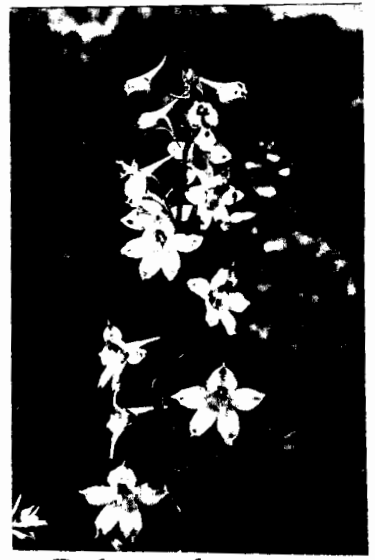

D. leucophaeum

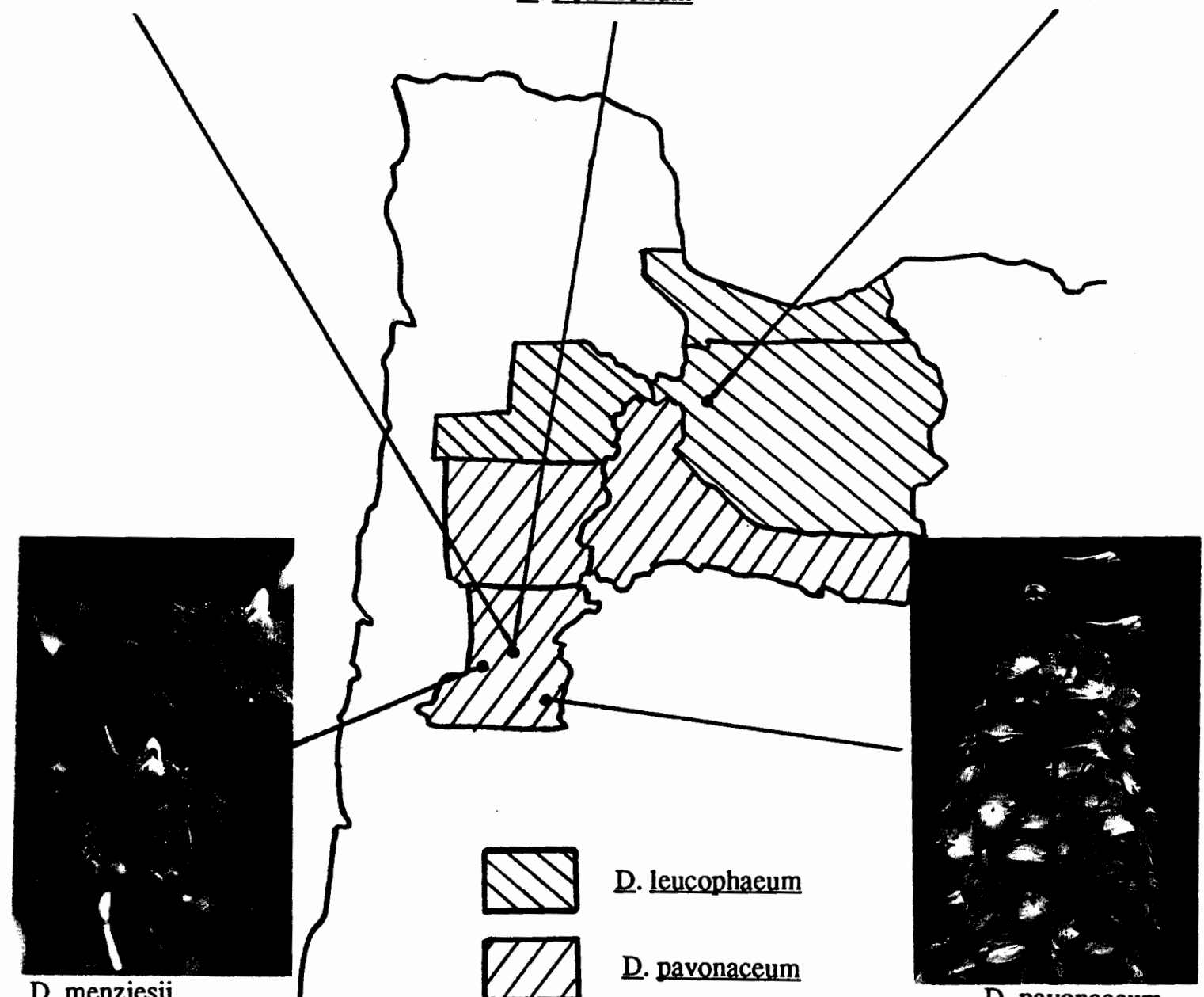

D. pavonaceum

Figure 1. Distribution of $\underline{D}$. leucophaeum and $\underline{D}$. pavonaceum in Oregon (Hitchcock and Cronquist, 1990). Dots mark collection sites. The Oregon Natural Heritage Program (1991) also reports possible sightings of D. leucophaeum in Marion County and Washington State (not on map). 


\section{METHODS}

\section{STUDY POPULATIONS}

The distribution of delphiniums in this study within the Willamette Valley shows scattered and occasionally mixed populations of the five species. Within these areas lie the field sites from which collections were made (Figure 1). Field sites were chosen from those in a recent study of Northwest Delphinium species by Goodrich (1985), upon whose thesis the following site descriptions are based. Ten sites, including one shared by three species, were visited over the course of three years. Seeds, flower buds and other structures were collected from five of those sites.

Although widespread in the Willamette Valley, only two $\underline{\text { D. trolliifolium populations }}$ were visited, one at Rock Creek Road and a small population a few miles north of Rock Creek in a dry rocky ditch along Highway 34 . Both populations consist of only one Delphinium species. The collection site lies approximately 50 meters south of Rock Creek Road leading to the Corvallis Watershed (elevation 122 meters). The delphiniums at this site are relatively tall plants with blueish purple sepals and petals and are found in large numbers in moist soil in a shaded glen near Rock Creek. A few of them can be seen at the border of the woods and a grassy field. Douglas fir, oaks and ash trees predominate. Many of the seed follicles of these plants were infested with insect larvae, particularly in 1991.

D. menziesii grows at both high and low elevations. Several populations exist in the Eugene area, in both isolated and disturbed areas. One small population is found at the interface of woods and meadow in Finley Wildlife Refuge, near Bellfountain Road. Samples of $\underline{\mathrm{D}}$. menziesii were collected from a large population in an open meadow facing 
south near the summit of Mary's Peak. At an elevation of about 1200 meters, these small delphiniums seem to find refuge from the cold in the thick vegetation.

Except for the large pure population south of McFarland Road, populations of D. pavonaceum near Corvallis are mixed, most with roughly equal numbers of the purple delphinium. Other populations in the Ankeny Wildlife Refuge near Salem are similarly mixed. One population along the road west of Eola contains four times as many D. pavonaceum as purple delphiniums, with many plants showing flowers intermediate in color between white and purple. Collections of $\underline{D}$. pavonaceum were made from a large unmixed population of about 1000 individuals located south of McFarland Road at the south end of Finley Wildlife Refuge, several miles south of Corvallis. This frequently soggy, open area of low-lying soil borders a marsh and has been seen flooded, with apparently no ill effect on these delphiniums. Rabbits have been seen here and may explain the occasional clean-cut removal of flowers. Infrequent holes in the flower buds indicate insect predation. Across the road is a smaller group of $\underline{D}$. pavonaceum that appear less robust and smaller in general than those to the south. Their dryer, rockier habitat is frequently dusted over by trucks going along the gravel road. Oak trees predominate.

Likely endemic to the northern Willamette Valley, large populations of D. leucophaeum are scattered throughout the Camassia Natural Area in West Linn, along basaltic cliffs in Lake Oswego, and on rocky islands in the Willamette River south of Willamette. Studies were made of plants on Little Rock Island. Plants grow in both shade and open areas in relatively sandy, often dry soil. They are commonly found among poison oak and at the edges of basalt cliffs.

The purple delphinium has been seen at Finley Wildlife Refuge both mixed with D. pavonaceum and alone along roadsides. A pure population of about 100 purple delphiniums is found in Ankeny Refuge and a small roadside population is found along Substation Road south of Corvallis, east of Highway 99. Approximately fifty meters north 
and on the other side of the road from the $\underline{D}$. trolliifolium population at Rock Creek Road lies a large population of the purple delphinium. A few $\underline{D}$. pavonaceum are mixed with these purple delphiniums in a narrow strip of land between a fence and the road. This area is exposed to the sun and soil ranges from wet to dry accordingly. More purple delphiniums were seen across the fence in a hayfield that has not been cut for a few years, apparently beginning to spread into the undisturbed area.

Sites visited

D. trolliifolium Rock Creek Road (south), Corvallis Watershed Highway 34, near Rock Creek Road

D. menziesii $\quad$ Finley Wildlife Refuge, Bellfountain Road Mary's Peak, near summit

D. pavonaceum McFarland Road, near Finley Wildlife Refuge

Ankeny Wildlife Refuge, near Salem

Rock Creek Road; mixed with purple delphinium

D. leucophaeum Little Rock Island, Willamette River

Rock Island, Willamette River

Camassia Nature Conservancy Refuge, West Linn

purple delphinium $\quad$ Rock Creek Road (north); mixed with $\underline{\text { D. pavonaceum }}$

Substation Road, south of Corvallis

Bruce Road, Finley Wildlife Refuge

\section{COLLECTIONS}

\section{$\underline{\text { Mitotic Tissues }}$}

Seed radicles, new roots and shoot meristems, pre-meiotic flower buds and cultured calluses and organs were sources of mitotic cells. 
Upon follicle dehiscence in late summer of 1989 and 1990, seeds were collected from one gynoecium per plant and from many plants of each species. They were stored in open envelopes at room temperature for two to four weeks to guarantee adequate dehydration prior to storing them at $6^{\circ} \mathrm{C}$ in airtight containers. Collections were made throughout the period of follicle dehiscence.

Seeds from different plants of each species were mixed together and thus the radicles that later emerged were mixed; individual plants were not distinguished. Observed karyotypes therefore represent a broad sample of individuals from each field site.

Low numbers of other meristematic tissues were collected in spring. Developing plants provided roots, shoot tips, axillary buds leaf buds and immature flower buds. Mature plants at each field site were uprooted gently, the few young translucent roots removed with forceps and fixed, and the plant replanted. This was done in the morning for a higher mitotic index (McRae, personal communication 1990). Shoot tips, leaf buds and axillary buds and pre-meiotic flower buds were removed from two or three plants of each species.

Calluses, leaves, shoot tips and roots were collected from in vitro cultured explants of mature delphiniums.

\section{Meiotic Tissues}

Young flower buds were collected from plants at each study site, two or three sepals removed to allow the fixative easy access to the anthers, and fixed in $3: 1$ of $95 \%$ ethanol : glacial acetic acid. The optimum bud length for obtaining meiotic cells was 3-4 millimeters. Tissues were stored in fixative in a freezer for later use.

\section{Explants}

Potted plants from the field were maintained in a garden and moved to the culture room for explant removal. This was done during the spring growth period. Various 
meristematic tissues were removed from these plants; shoot tips, immature flower buds, stems, leaves, leaf buds, and corms.

\section{Transplants}

Several plants of each species were transplanted to my backyard for observation.

\section{CYTOGENETICS}

\section{$\underline{\text { Mitosis }}$}

Meristems collected in the field, seed radicles and the products of in vitro cultivation were pretreated in $0.1 \%(\mathrm{w} / \mathrm{v})$ colchicine at room temperature for two, three or four hours immediately after collection and then fixed in $3: 1$ of $95 \%$ ethanol : glacial acetic acid. Some tissues were not pretreated with colchicine in order to have a control.

Prior to staining, tissues were removed from the fixative, macerated in $1 \mathrm{~N} \mathrm{HCl}$ at $60-65^{\circ} \mathrm{C}$ for $13-15$ minutes and washed in fixative for a minimum of five minutes. Roots and radicles were placed on a glass slide and all but 1 millimeter of the tips was removed. Other tissues were cut into pieces about one millimeter in diameter (too much tissue inhibits the spreading of cells and chromosomes). The excess wash was removed, a drop of orcein stain (G.T. Gurr's) was added and the tissue crushed well with the blunt end of an aluminum rod. A coverglass was added and the material allowed to stain for 45 60 minutes. The coverglass was tapped hard with the pointed end of the aluminum rod to spread the cells apart, the slide heated over an alcohol lamp briefly for further cell and chromosome spreading and then squashed hard under a thumb. Most mitotic material consisted of laboratory germinated seed radicles (see section on seed germination for details).

Premeiotic flower buds were transferred from the fixative to $1 \mathrm{~N} \mathrm{HCl}$ at $60-65{ }^{\circ} \mathrm{C}$ for eight minutes and washed in fixative for a minimum of five minutes. They were placed on 
a glass slide, all but the anthers was removed, and excess wash was absorbed. Anther contents were forced out and anther walls were removed. A drop of orcein stain was placed on the anther contents. The anther contents were covered with a coverglass and allowed to stain for 30 - 45 minutes. The coverglass was tapped with a rod and the slide was heated briefly over an alcohol flame and then squashed.

Chromosome studies were done with a Zeiss microscope and cells were microphotographed with a Zeiss Ikon at 1000X magnification with a Neofluar 100/1,300 el objective. Half-second exposures of Kodak technical pan film 2415 produced negatives that were printed on Kodak Polyfiber paper using an Omega 2D enlarger.

The numbers of organs and cells examined are listed in Table II.

\section{Karyotype and Idiogram Construction}

Prints of microphotographed chromosomes of seed radicles were used for karyotype construction. The negatives of ten cells from each species with well spread, relatively straight metaphase chromosomes were printed at the same enlargement for measuring purposes.

For idiogram construction, variation in chromosome size due to differential contraction was minimized by measuring only well contracted chromosomes at mid-metaphase (shorter and more condensed than pro-metaphase chromosomes but not overly condensed). Only colchicine treated chromosomes were measured for comparing species, but chromosomes that had not been subjected to colchicine pretreatment were also measured as a control. Photographed chromosomes were measured and classified according to the system of Levan et al. (1964) (see Appendix A) and numbered from 1 to 8 in order of decreasing length. Indistinguishable chromosomes 3 - 6 were labeled "group B". Identification of homologue pairs was determined by chromosome size and centromere location. Satellites were positioned on identifiable chromosomes. 
TABLE II

NUMBER OF ORGANS AND CELLS PHOTOGRAPHED AND/OR SCORED

\begin{tabular}{lccccc}
\hline \multirow{2}{*}{ Species } & \multicolumn{2}{c}{ Roots } & \multicolumn{2}{c}{ Other Tissues 1} & Meiotic \\
\cline { 2 - 6 } D. trolliifolium & Roots & Cells & Tissues & Cells & Cells \\
D. menziesii & 73 & 182 & 32 & 31 & 25 \\
D. pavonaceum & 59 & 216 & 7 & 8 & 29 \\
D. leucophaeum & 97 & 143 & 27 & 91 & 31 \\
purple delphinium & 45 & 120 & 60 & 50 & 73 \\
\hline Total & 133 & 132 & 18 & 19 & 37 \\
\hline
\end{tabular}

$1_{\text {other tissues }}=$ pre-meiotic flower buds, shoot and leaf buds and products of in vitro culture 
Chromosome arm lengths were estimated to the nearest 0.5 millimeters and converted to micrometers by determining the scale with a stage micrometer. Measurements were influenced by occasionally indistinct telomeres and the subjective nature of measuring by eye.

No size scale was given for the California species; relative chromosome lengths were calculated from the data in the literature and then absolute lengths were calculated, based on the average genome length of the Oregon species for the sake of comparison.

\section{Statistical Analysis of Mitotic Chromosomes}

Mean chromosome arm ratios, relative lengths and lengths of 20 chromosomes (10 cells) per species were calculated and analyses of variance of the means for all five species were performed. Only chromosomes $1,2,7$ and 8 were analysed. Those mean values that were found to be significantly different among species were then subjected to Fisher's LSD Multiple Comparison Test in order to determine how the species were grouped.

\section{$\underline{\text { Meiosis }}$}

Flower buds were removed from the fixative, macerated in $1 \mathrm{~N} \mathrm{HCl}$ at $60-65^{\circ} \mathrm{C}$ for three minutes and washed in fixative for a minimum of five minutes. Each bud was placed on a glass slide; excess wash and all tissues but the anthers were removed. Anther contents were coaxed out onto the slide and the anther walls removed. The anther contents were stained with orcein. A coverglass was added and after 45 minutes the slide was heated briefly over an alcohol flame and gently squashed.

The number of cells photographed are listed in table II.

\section{REPRODUCTION}

\section{Pollen Viability}

Pre-dehiscent anthers were collected from plants in the field and stored several days at 
$6{ }^{\circ} \mathrm{C}$ prior to staining. A small amount of pollen was squashed out of the anther onto a glass slide. A malachite green-acid fuchsin pollen stain developed by Alexander (1969) was added and a coverglass applied. Several hours later aborted pollen grains could be distinguished from viable ones by color (red and green respectively). Pollen of anthers from ten plants of $\underline{D}$. trolliifolium, and two plants each of $\underline{D}$. pavonaceum and the purple delphinium were stained. One to five pollen counts were made from each slide .

\section{Pollen Germination}

Dehiscent anthers were collected and stored at $6{ }^{\circ} \mathrm{C}$ several days prior to proceeding. Several small drops of a 1:1 solution of $10 \%$ sugar and $20 \mathrm{ppm}$ boric acid were scattered onto a cover glass and a very small amount of pollen was dusted on the sugar solution. The coverglass was turned pollen-side down over a depression slide that was moistened to seal the coverglass. The slide was placed on damp paper in a covered Petri dish and left at $22-25^{\circ} \mathrm{C}$. After $2-12$ hours, the presence of pollen tubes was noted.

\section{Seed/Ovule Ratios}

In most cases, three follicles of one flower per plant were collected prior to dehiscence. Follicles with a normal appearance were chosen for consistency as some plants had abnormal follicles due to predation or developmental problems. The number of viable seeds and the number of undeveloped ovules in each follicle were recorded. Only tiny, shrunken seeds were considered undeveloped, since small discolored seeds are known to germinate. The percentage of viable seeds was calculated by dividing the number of viable seeds by the total number of seeds and ovules and then multiplying by 100 .

\section{$\underline{\text { Seed Germination }}$}

Seeds of each of the five Oregon species were set up for germination in a transfer hood under sterile conditions to reduce the possibility of fungal contamination. Petri dishes were 
filled five millimeters deep with vermiculite. Filter paper was placed over the vermiculite and the dishes covered and sterilized. The paper and vermiculite were saturated with sterile distilled water. Dry, cold-stored seeds were soaked in a $10 \%$ bleach solution for 10 minutes and thoroughly washed in sterile, distilled $\mathrm{H}_{2} \mathrm{O}$. The seeds were spread out over the wet filter paper, covered and placed in plastic bags to prevent drying. Seeds of all five species were chilled at $6^{\circ} \mathrm{C}$ for four to five weeks to break dormancy and then exposed to four different temperatures in order to determine optimum germination conditions. A few seeds were not chilled prior to germination in order to verify that stratification is required. They were left at 6,12 , or $22^{\circ} \mathrm{C}$ or placed outdoors for exposure to winter temperatures. Seeds were in the dark except for brief periods for observation or radicle collection.

Once the optimum conditions were established, more seeds were set up in order to obtain data on reproductive potential. The resulting seed radicles of each species were counted at one to two week intervals. Many were pretreated and fixed for later chromosome staining. After a period of no germination activity, the remaining ungerminated seeds were counted. Seed percentages were calculated by dividing the number that germinated by the total number of seeds and then multiplying by 100 .

\section{TISSUE CULTURE}

\section{Tissue Culture}

Tissues were removed (explants) from developing delphiniums, washed in water and soaked in a $10 \%$ bleach solution for twenty minutes, then rinsed three times in sterile water. Care was taken to maintain sterile conditions, as mold is a common problem. The tissue was cut into desirable sizes, placed in sterile media in a test tube and covered with paraffin. The tubes were placed about eight inches below grow lights (40W Vita-lite) 24 hours a day at approximately $21^{\circ} \mathrm{C}$.

The basic Murashige \& Skoog medium (Sigma Chemical Company, St. Louis, 
Missouri 1990) was prepared and various concentrations and ratios of auxin (1-napthaleneacetic acid) and cytokinin (6-benzyladenine) were added (Appendix B). 


\section{RESULTS}

\section{CYTOGENETICS}

\section{$\underline{\text { Mitosis }}$}

Delphinium trolliifolium, $\underline{\text { D. menziesii, }} \underline{\text { D. pavonaceum, }}$ D. leucophaeum and the purple delphinium are diploid: $2 n=16$. Polyploid cells were infrequent and likely due to the effects of colchicine. All five karyotypes were similar in size and morphology and consisted of two large and six smaller chromosome pairs (Figures 2 and 3).

The karyotype similarity allowed for the construction of a composite haploid idiogram (Figure 4). Arm ratios and lengths for this composite were based on an average of fifty cells, ten cells per species. The haploid chromosome complement consists of two long chromosomes (numbers 1 and 2), four intermediate in length (group B) and two shorter ones (numbers 7 and 8 ). The two long chromosomes can be distinguished by centromere location; chromosome 1 is metacentric and 2 is submetacentric. Chromosomes in group B and chromosome 7 are subtelocentric and chromosome 8 is submetacentric. In all species, chromosomes in group B are indistinguishable (their arrangement in idiograms and karyotypes is based on small and possibly artificial differences in arm ratio and overall length). Therefore, these four chromosomes were not numbered individually and satellites, although seen on members of this group, are not assigned to particular chromosomes in the group.

The means and standard deviations of arm ratios, relative chromosome lengths and absolute chromosome lengths of the four identifiable nonhomologous chromosomes of each species are given in Table III. A pattern can be seen when comparing the mean length of the four different chromosomes among the species. Corresponding chromosomes in the 
purple delphinium

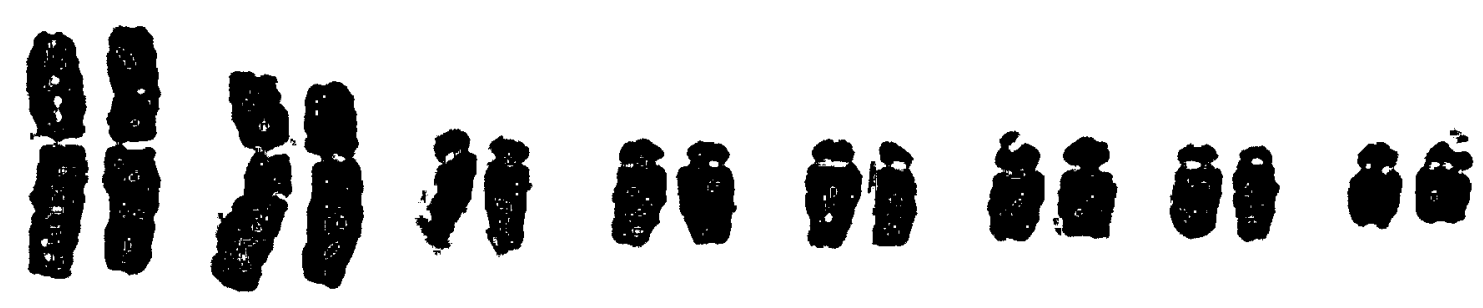

D. trolliifolium

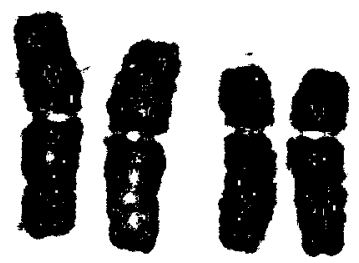

\author{
D. menziesii
}

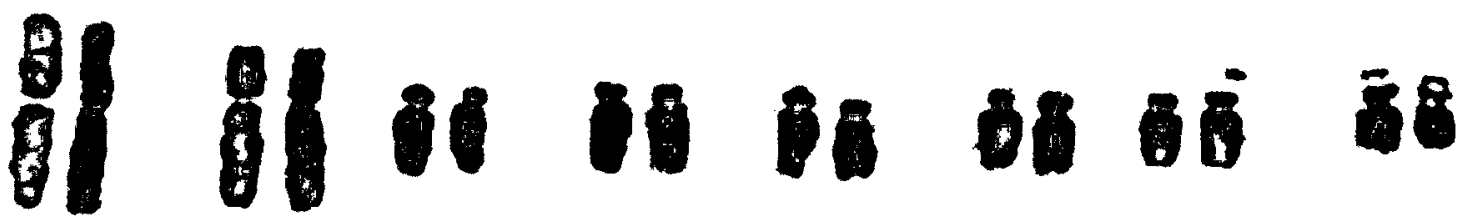

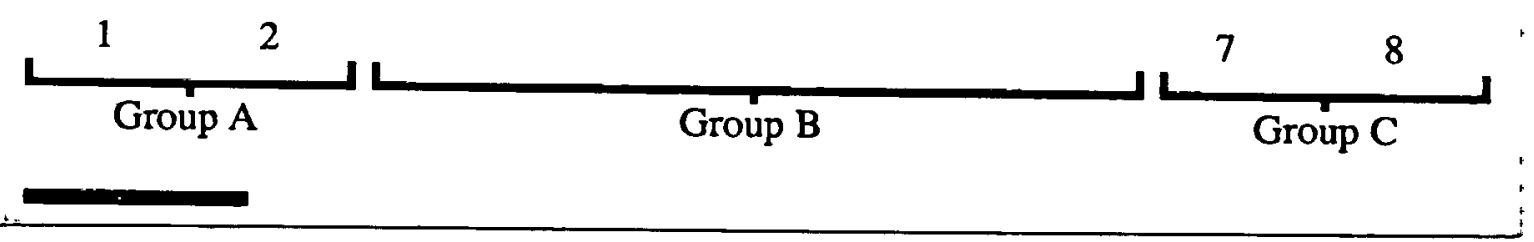

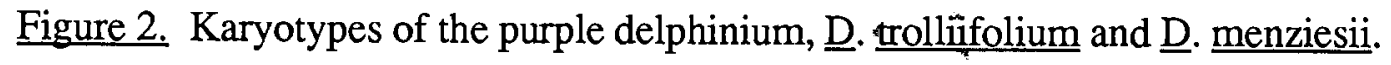
Bar equals $10 \mu \mathrm{m}$. 
D. pavonaceum

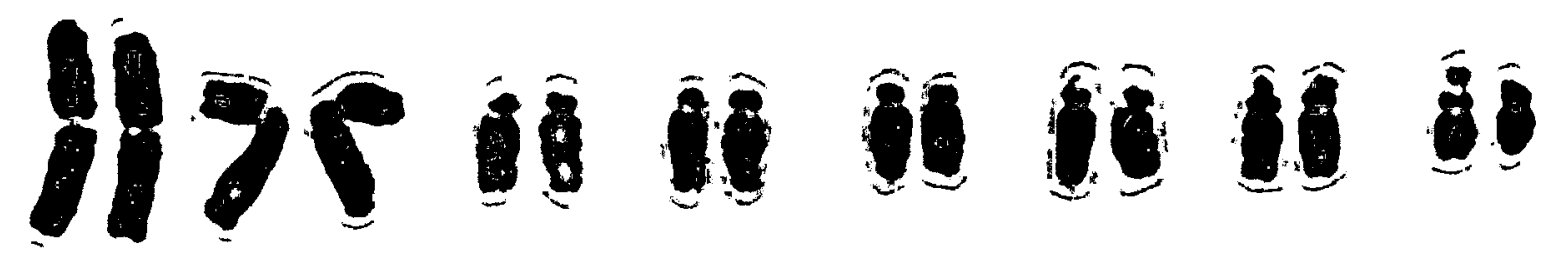

D. leucophaeum

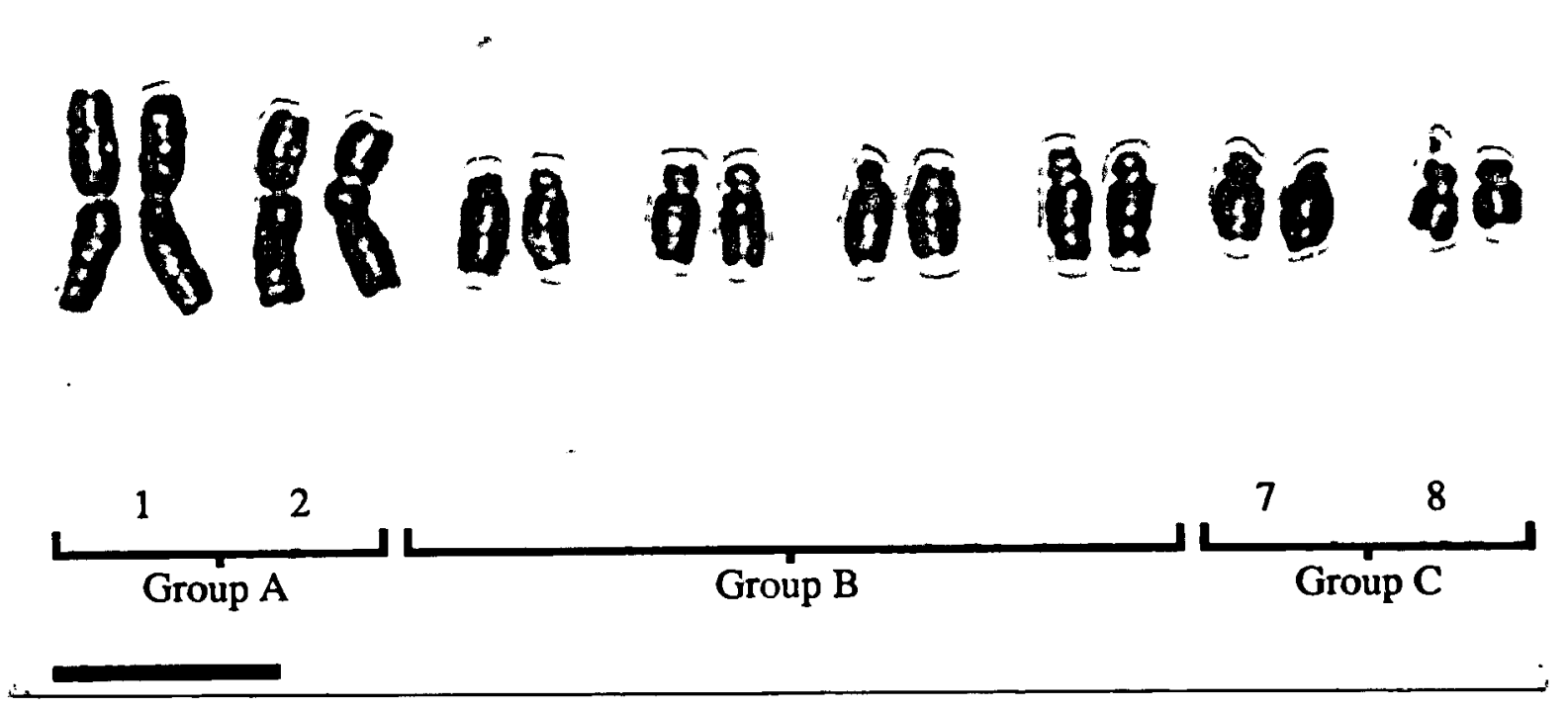

Figure 3. Karyotypes of $\underline{\mathrm{D}}$. pavonaceum and $\underline{\mathrm{D}}$. leucophaeum. $\mathrm{Bar}=10 \mu \mathrm{m}$. 


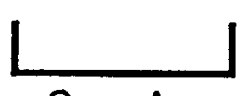

Group A

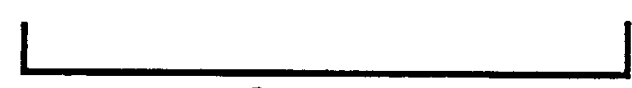

Group B

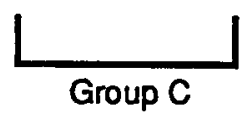

bar $=1 \mu \mathrm{m}$

Figure 4. Composite idiogram of Oregon Delphinium species. Idiogram is based on the means of chromosome measurements of fifty cells (ten cells per species). 
TABLE III

\section{SUMMARY OF CHROMOSOME MEASUREMENTS OF OREGON DELPHINIUMS}

\begin{tabular}{|c|c|c|c|c|c|c|}
\hline $\begin{array}{c}\text { Chrom. } \\
\text { No. } \\
\end{array}$ & Value & $\begin{array}{l}\text { D.trollii } \\
\text { folium }\end{array}$ & $\begin{array}{c}\text { purple } \\
\text { delphinium } \\
\end{array}$ & $\begin{array}{l}\text { D.pavo } \\
\text { naceum } \\
\end{array}$ & $\begin{array}{l}\text { D. leuco- } \\
\text { phaeum }\end{array}$ & D. menziesii \\
\hline \multirow[t]{3}{*}{1} & ratio & $1.3(0.19)$ & $1.2(0.18)$ & $1.3(0.13)$ & $1.2(0.09)$ & $1.2(0.13)$ \\
\hline & rel. 1. & $24.3(0.04)$ & $24.0(0.04)$ & $25.0(0.04)$ & $24.2(0.03)$ & $25.4(0.04)$ \\
\hline & length & $10.1(1.60)$ & $9.9(1.69)$ & $9.4(1.70)$ & $9.1(1.46)$ & $9.3(0.99)$ \\
\hline \multirow[t]{3}{*}{2} & ratio & $2.1(0.23)$ & $2.1(0.25)$ & $2.0(0.26)$ & $1.9(0.29)$ & $1.9(0.23)$ \\
\hline & rel. 1. & $21.4(0.04)$ & $21.4(0.03)$ & $20.5(0.03)$ & $20.2(0.03)$ & $20.2(0.03)$ \\
\hline & length & $8.8(1.49)$ & $8.8(1.33)$ & $7.7(1.21)$ & $7.5(1.27)$ & $7.5(0.92)$ \\
\hline \multirow[t]{3}{*}{7} & ratio & $4.1(0.78)$ & $4.0(0.83)$ & $3.7(0.95)$ & $4.0(0.94)$ & $4.2(1.18)$ \\
\hline & rel. 1. & $8.4(0.01)$ & $8.7(0.02)$ & $8.7(0.01)$ & $9.0(0.01)$ & $8.6(0.01)$ \\
\hline & length & $3.5(0.53)$ & $3.5(0.61)$ & $3.3(0.33)$ & $3.4(0.32)$ & $3.2(0.23)$ \\
\hline \multirow[t]{3}{*}{8} & ratio & $3.4(0.82)$ & $3.0(0.97)$ & $2.5(0.64)$ & $2.9(0.87)$ & $2.9(0.76)$ \\
\hline & rel. 1. & $6.7(0.06)$ & $6.4(0.01)$ & $6.8(0.01)$ & $7.2(0.01)$ & $6.7(0.01)$ \\
\hline & length & $2.7(0.50)$ & $2.7(0.55)$ & $2.5(0.39)$ & $2.6(0.37)$ & $2.5(0.21)$ \\
\hline haploid & total & 41.5 & 41.1 & 37.8 & 37.9 & 37.0 \\
\hline \multicolumn{7}{|c|}{$\begin{array}{l}\text { Note: all values are the means of each species (standard deviations in parentheses) } \\
\text { ratio = long arm length divided by short arm length }(\mu \mathrm{m}) ; \mathrm{L} / \mathrm{S} \\
\text { length = total length }(\mu \mathrm{m})=\text { length of chromosome excluding centromere; } \mathrm{L}+\mathrm{S} \\
\text { rel. } 1 .=\text { relative length }(\%)=\text { length of chromosome } \times 100 / \text { length of haploid genome } \\
\text { haploid total = total length }(\mu \mathrm{m}) \text { of haploid complement }\end{array}$} \\
\hline
\end{tabular}


genomes of $\underline{D}$. trolliifolium and the purple delphinium are identical in length or nearly so. Although there is a wider range among the other three species, they are more similar to each other than they are to $\underline{D}$. trolliifolium and the purple delphinium. As a whole, there is a gradation in chromosome sizes from the longest genome of $\underline{D}$. trolliifolium to the shortest of $\underline{\text { D. menziesii. }}$.

A comparison of the means of chromosome measurements of the five Oregon species revealed, for three of the values, significantly greater variances among the species than within any one species (significance level $=5 \%)$. The arm ratios of chromosome $2(\mathrm{df}=4$, $\mathrm{F}=2.85, \mathrm{p}=0.0279)$ and chromosome $8(\mathrm{df}=4, \mathrm{~F}=2.99, \mathrm{p}=0.0225)$ and the length of chromosome $2(\mathrm{df}=4, \mathrm{~F}=5.97, \mathrm{p}=0.0002)$ are significantly different among the species. The multiple comparison test showed a consistent grouping of the species for all three values (Figure 5). Note that $\underline{\mathrm{D}}$. leucophaeum, $\underline{\mathrm{D}}$. pavonaceum and $\underline{\mathrm{D}}$. menziesii are

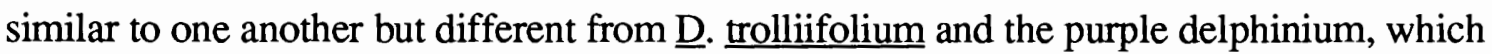
are grouped together.

Satellites appear on the short arms of chromosomes 7 and 8 and chromosomes in the B group and are absent from chromosomes 1 and 2 in all five species. At least four nonhomologous satellited chromosomes (chromosomes 7, 8 and two chromosomes in the B group) are present in the haploid set of all species except $\underline{D}$. leucophaeum, a species in which only three were verified. In this case, satellites were present on chromosomes 7,8 and one chromosome in the B group (Table IV). The numbers of nonhomologous satellited chromosomes may be greater than indicated but the inability to distinguish chromosomes in the B group precludes a more precise account. A wide range in the number of visible satellites exists between plants within each species and even between cells within an individual. Satellites were clearly visible on one or both homologues of chromosome 8 in the majority of examined cells of all five species. Examples of satellites can be seen in the photographs in Figures 6,7 and 8. 
Mean Value $\quad$ Species Grouped

\section{Chromosome 2}

\begin{tabular}{|c|c|c|}
\hline \multirow[t]{2}{*}{ Arm Ratio } & D. leucophaeum - & [D. trolliifolium \\
\hline & D. menziesii & - purple delphinium \\
\hline Length & $\begin{array}{l}\text { D. leucophaeum } \\
\text { D. menziesii } \\
\text { D. pavonaceum }\end{array}$ & {$[\underline{\text { D. trolliifolium }}$ purple delphinium } \\
\hline
\end{tabular}

\section{Chromosome 8}

$$
\text { Arm Ratio } \quad \underline{\text { D. pavonaceum }}-\left[\frac{\text { D. trolliifolium }}{\text { purple delphinium }}\right.
$$

Figure 5. Species grouped according to differences in their mean chromosome measurements. Brackets indicate similar means and horizontal lines indicate significant differences in the means. For each value, unlisted species are similar to all those listed. 
TABLE IV

MINIMUM NUMBER OF NONHOMOLOGOUS SATELLITED CHROMOSOMES IN A HAPLOID SET

\begin{tabular}{lc}
\hline \multicolumn{1}{c}{ Species } & $\begin{array}{c}\text { Number of } \\
\text { Chromosomes } 1\end{array}$ \\
\hline D. trolliifolium & 4 \\
D. menziesii & 4 \\
D. pavonaceum & 4 \\
D. leucophaeum & 3 \\
purple delphinium & 4 \\
rumber of chromosomes out of a total of ten \\
cells per species
\end{tabular}




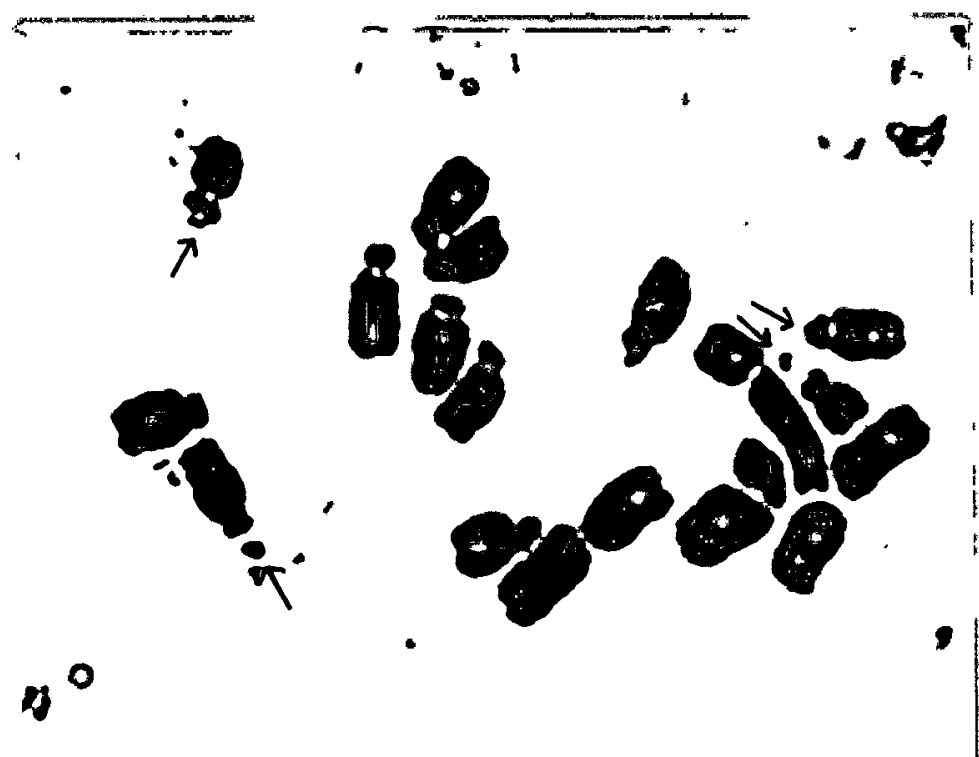

D. pavonaceum

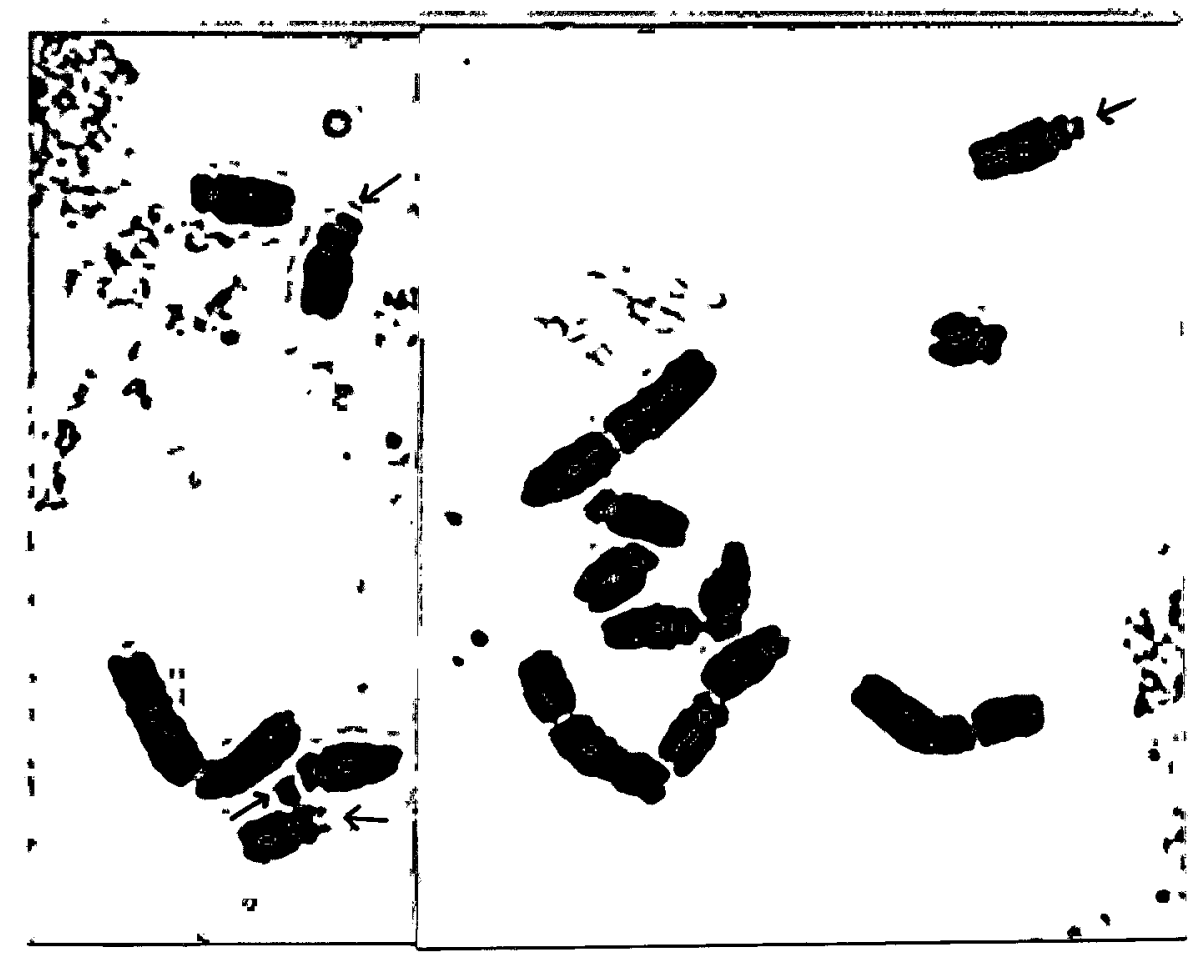

D. menziesii

Figure 6. Satellites of $\underline{D}$. pavonaceum and $\underline{D}$. menziesii. Satellites at arrows. 


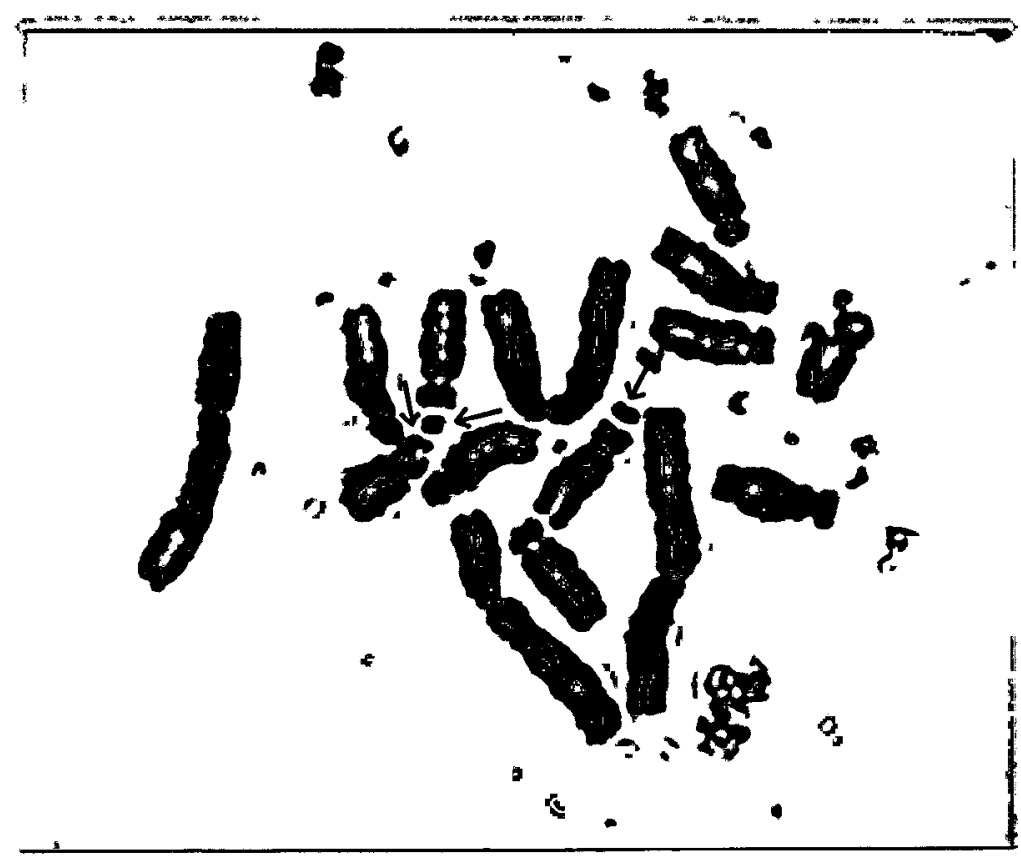

purple delphinium

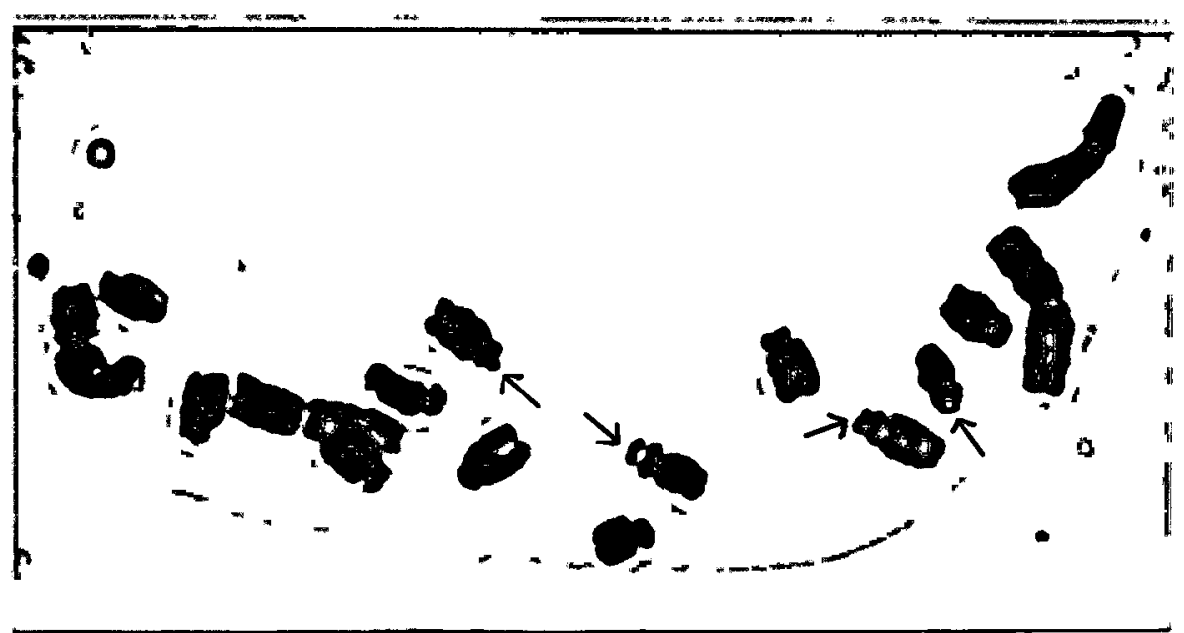

D. leucophaeum

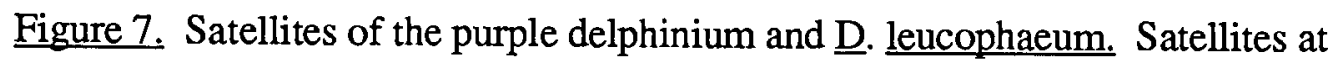
arrows. 


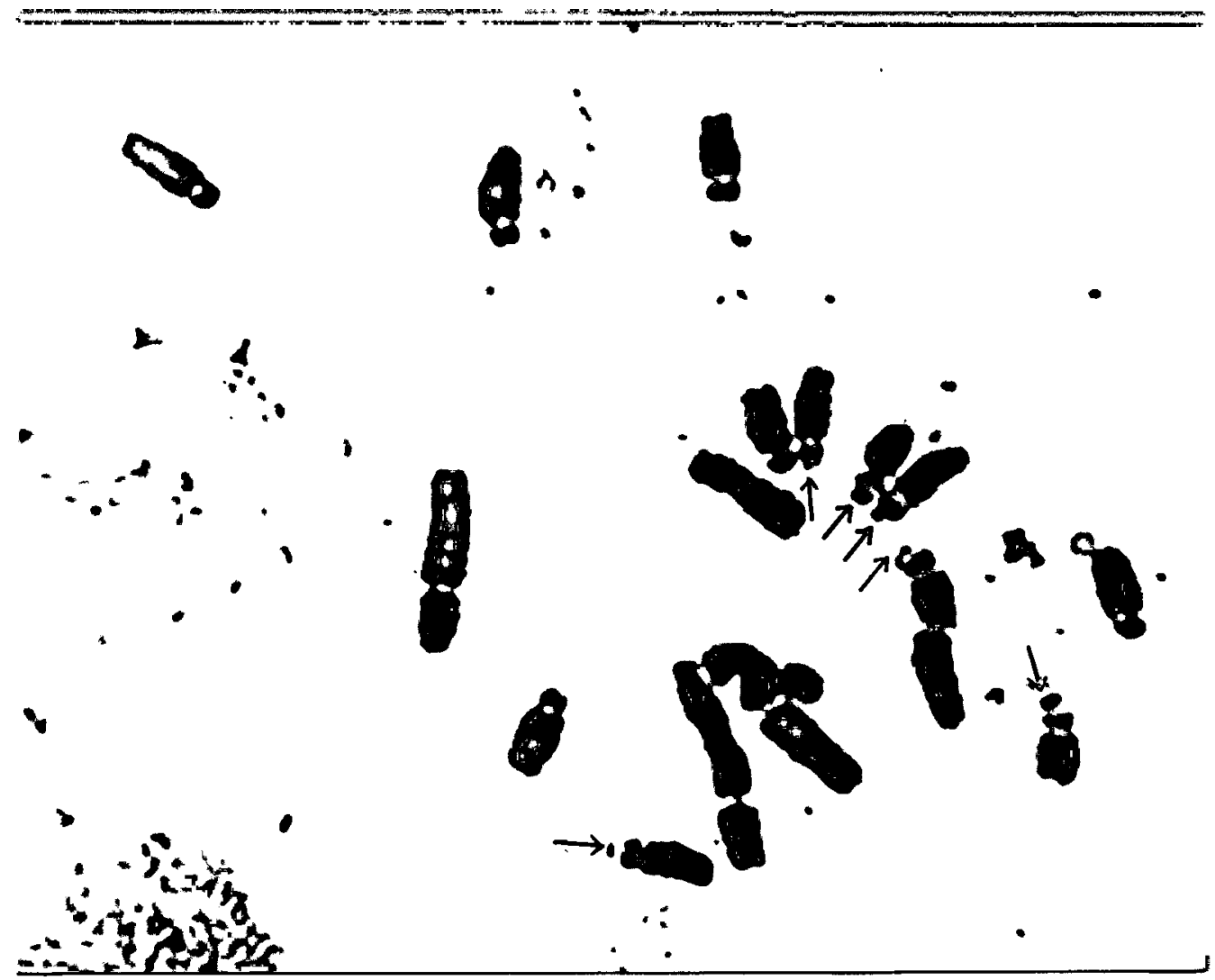

Figure 8. Satellites of D. trolliifolium. Satellites at arrows. 
A curious secondary constriction in the long arm of one chromosome in the B group was seen in some cells, more notably and consistently in those of $\underline{\mathrm{D}}$. trolliifolium and the purple delphinium (Figure 9). Only one chromosome per cell exhibited this constriction. In the majority of the metaphase cells of the five species, all but chromosomes 1 and 2 are usually in groups of two or more and are closely associated in the region of their short arms. Frequently, a satellite or two is present as well. Non-homologous associations are frequent (Figure 10,11 and 12). Cells that were pretreated in colchicine appear similar to untreated cells relative to this phenomenon; it is thus likely not an artifact.

Cells of one seed radicle of $\underline{D}$. trolliifolium contain two largely unmatched sets of chromosomes, suggestive of intergeneric hybridization. One subtelocentric chromosome was unusually long and occasionally observed to have a satellite (Figure 13).

\section{$\underline{\text { Meiosis }}$}

Late metaphase - early anaphase I configurations of these five Oregon species are similar (Figures 14 and 15). The 16 chromosomes form eight bivalents, two of which are large and ring-shaped. The other six bivalents look like rods or barbells. The ring bivalent of chromosome 1 is nearly symmetrical in contrast to the asymmetrical ring of the paired submetacentric chromosomes 2. The six smaller chromosomes are indistinguishable except for the shorter, stubby rod that is likely the bivalent of chromosome 8 .

Although chiasmata have largely terminalized by this stage, some can still be seen. No more than two chiasmata were seen on any arm of any bivalent. Bivalent of chromosome 1 had one or possibly two (there are signs of a second that had terminalized) in either arm. Bivalent of chromosome 2 had one chiasma in each arm and possibly two in the long arm. In the case of the purple delphinium, two chiasmata were visible in the long arms of bivalent 2. Although no chiasmata were observed in either arm of the smaller chromosomes, it can be safely assumed that one had formed between the long arms of each 


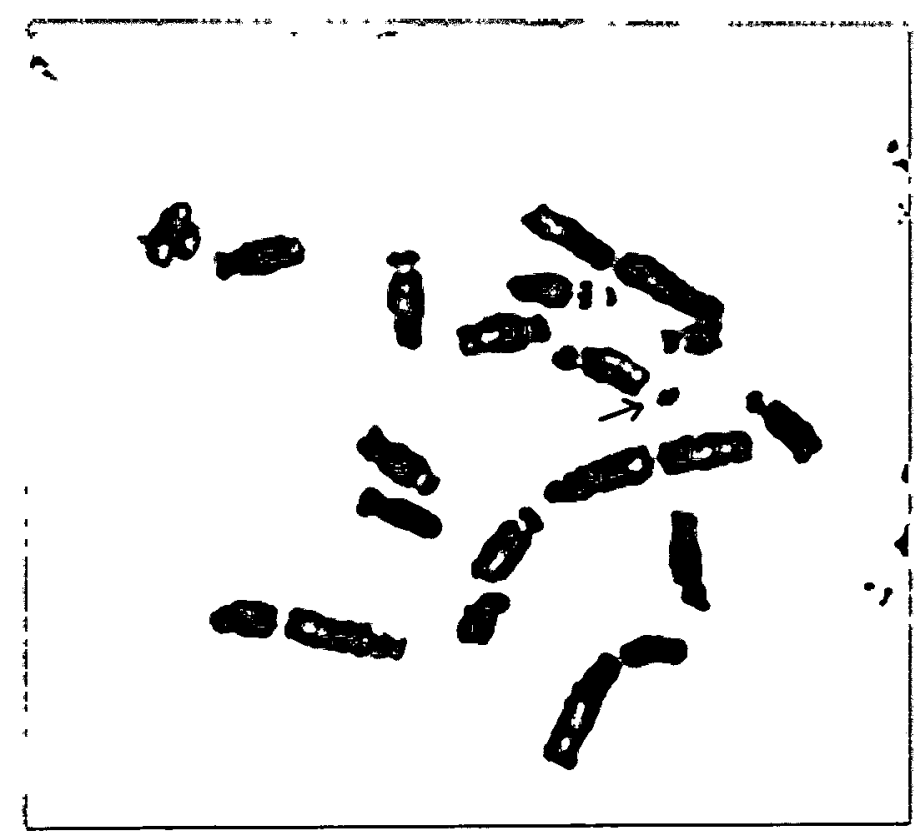

purple delphinium

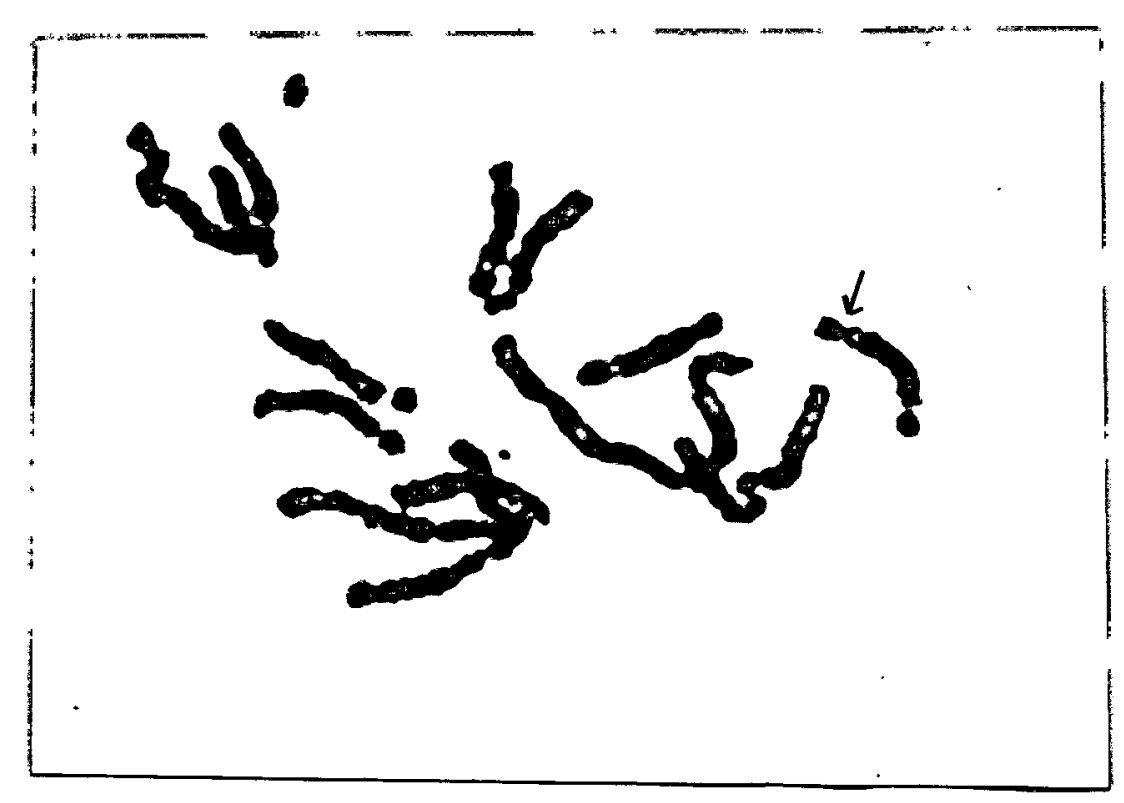

D. trolliifolium

Figure 9 . Secondary constriction in the purple delphinium and $\underline{D}$. trolliifolium. 


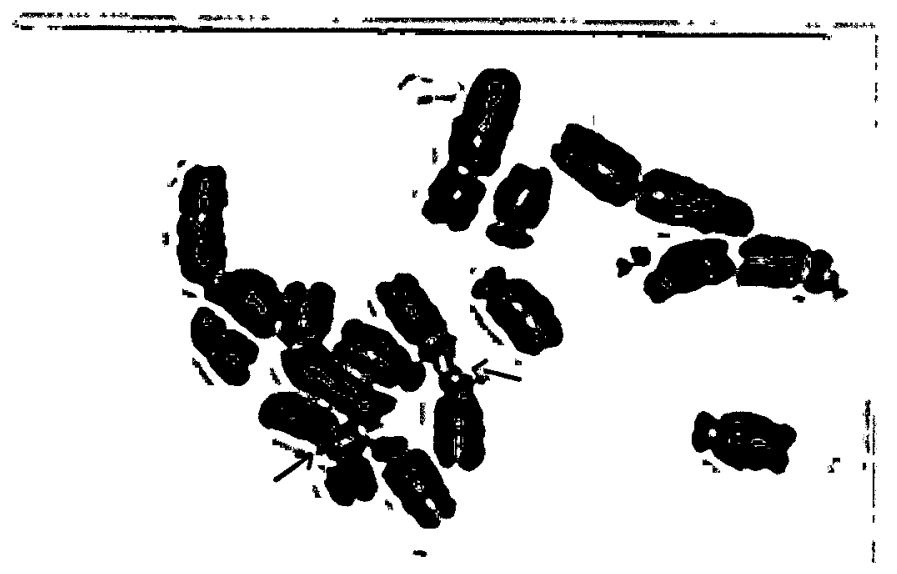

D. $\underline{\text { leucophaeum }}$

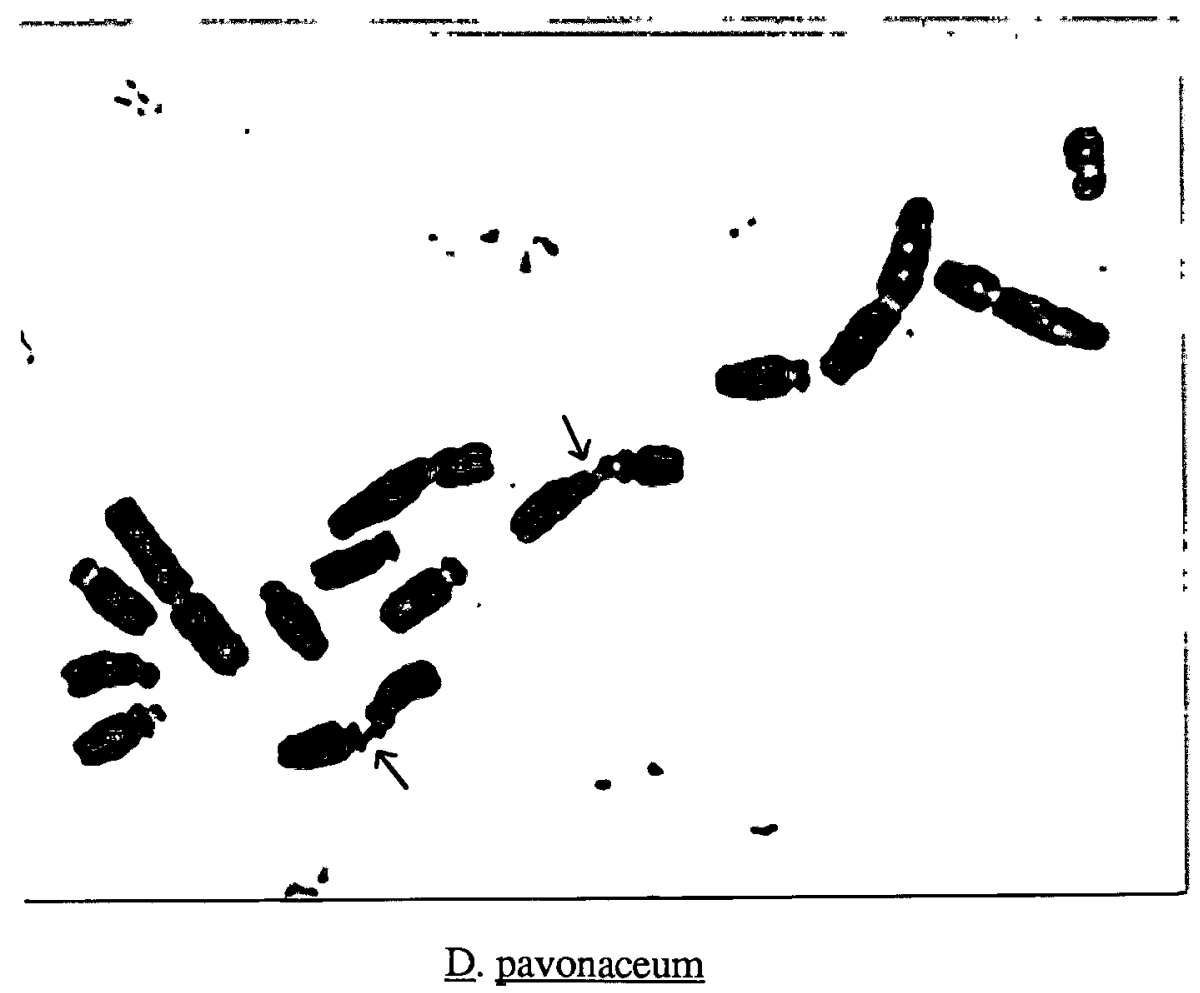

Figure 10. Associated chromosomes in $\underline{\mathrm{D}}$. leucophaeum and $\underline{\mathrm{D}}$. pavonaceum. Note arrows. 


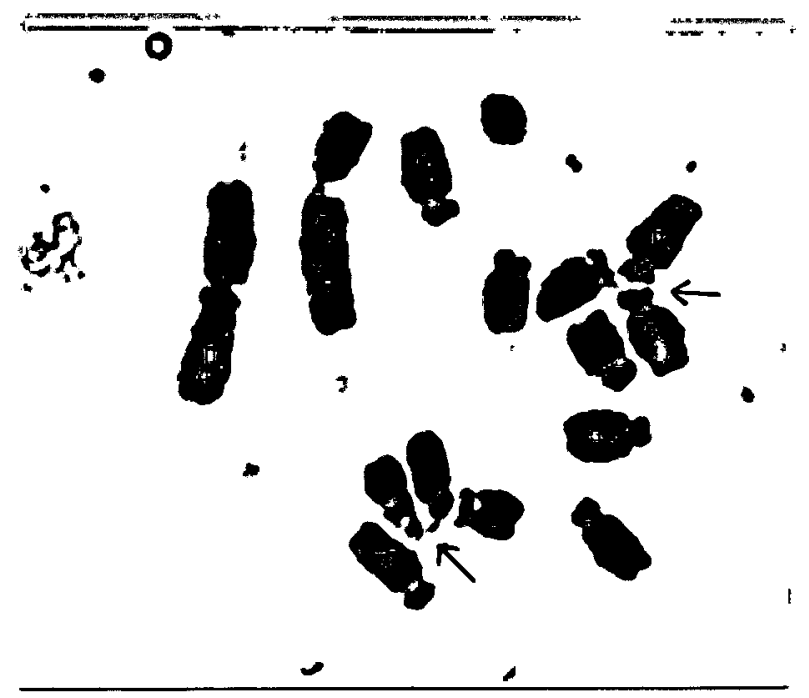

D. trolliifolium

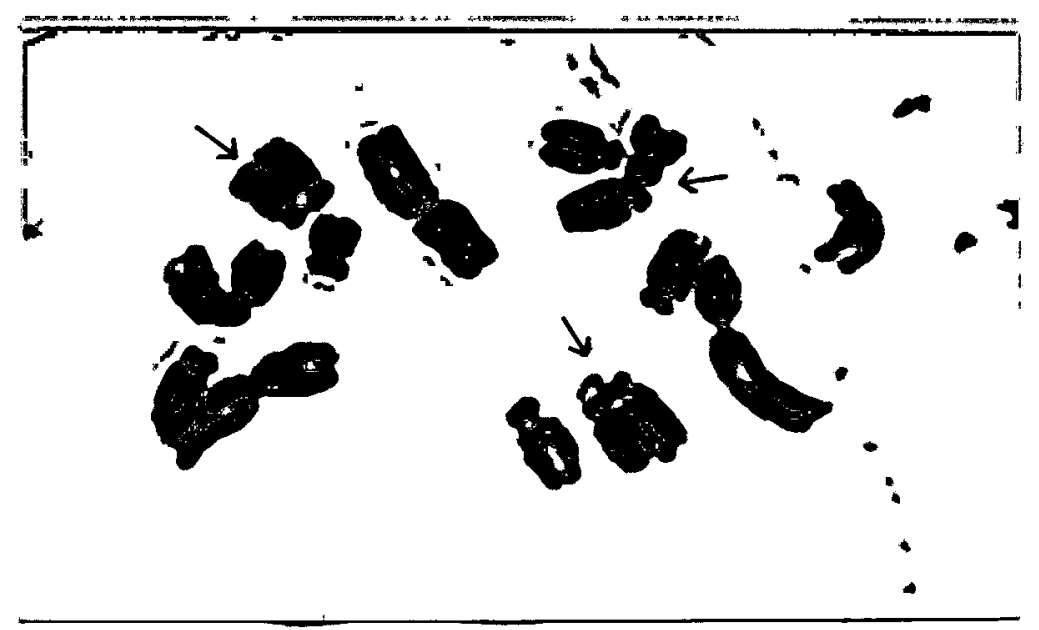

purple delphinium

Figure 11. Associated chromosomes in D. trolliifolium and the purple delphinium. Note arrows. 


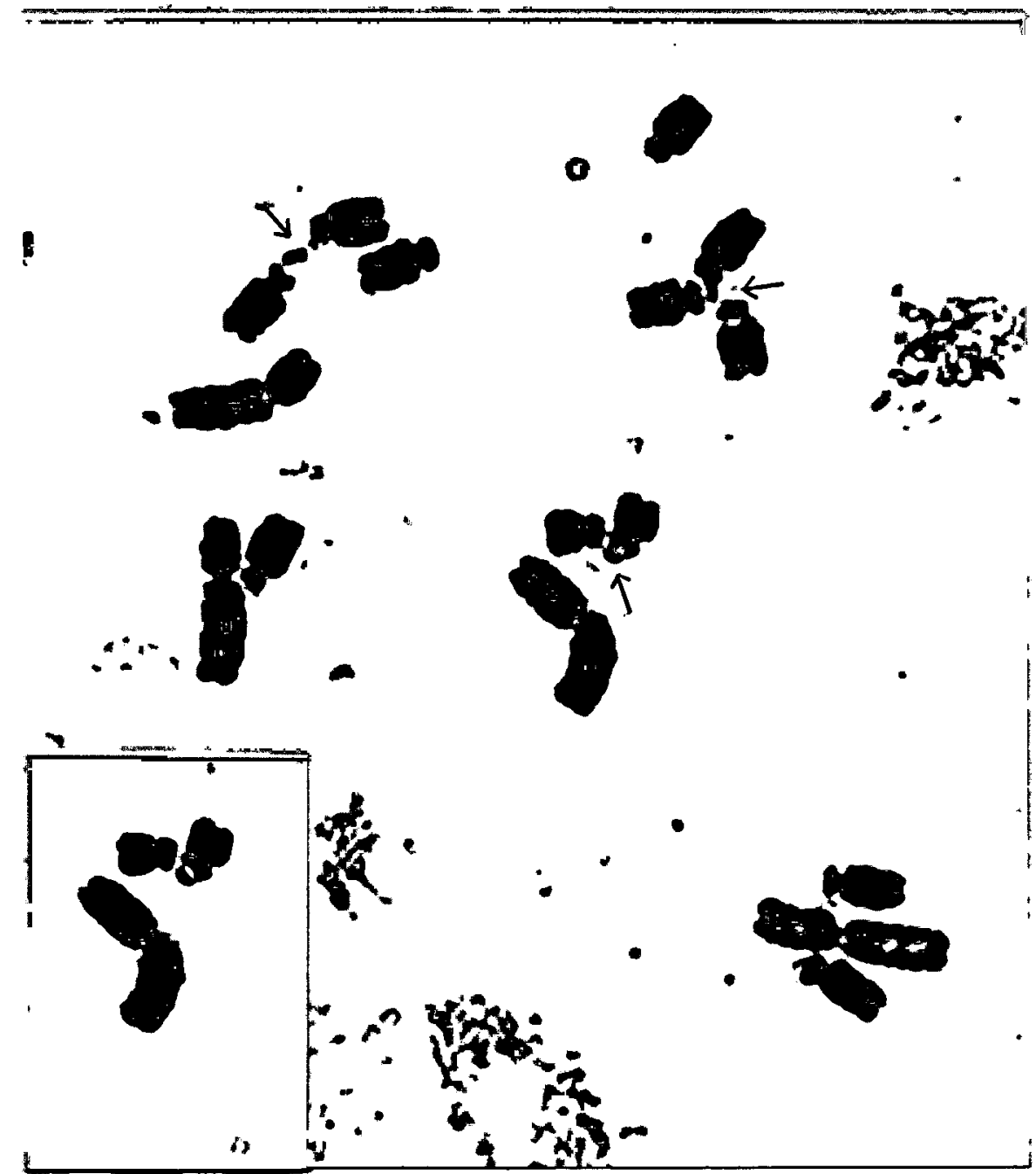

Figure 12. Associated chromosomes in D. menziesii. Note arrows. Inset: improved focus of chromosomes in the center of the photograph. 


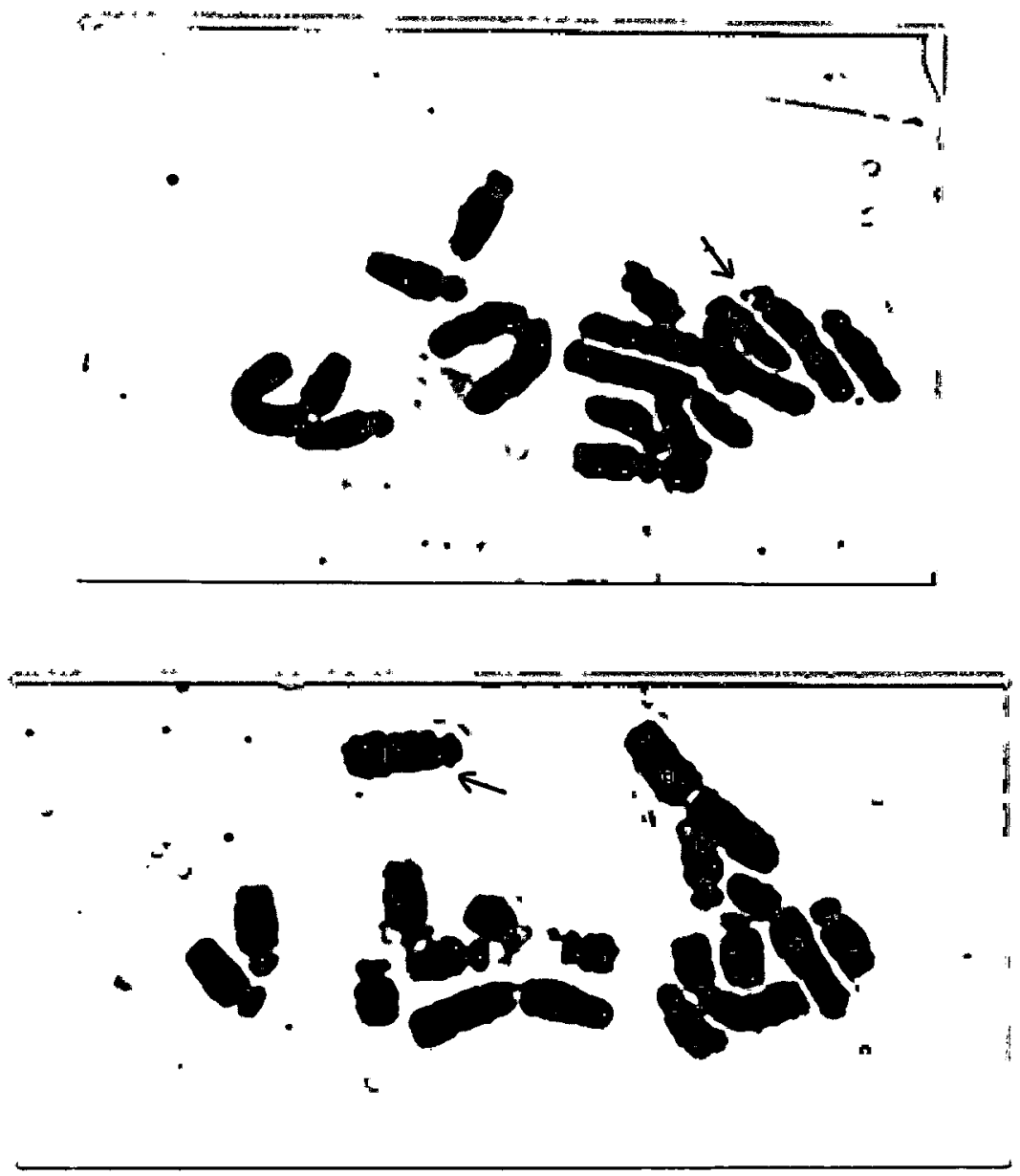

Figure 13. Strange set of of chromosomes in two cells of one $\underline{D}$. trolliifolium plant. The unusually long subtelocentric chromosome is at the arrow. Note the satellite. 


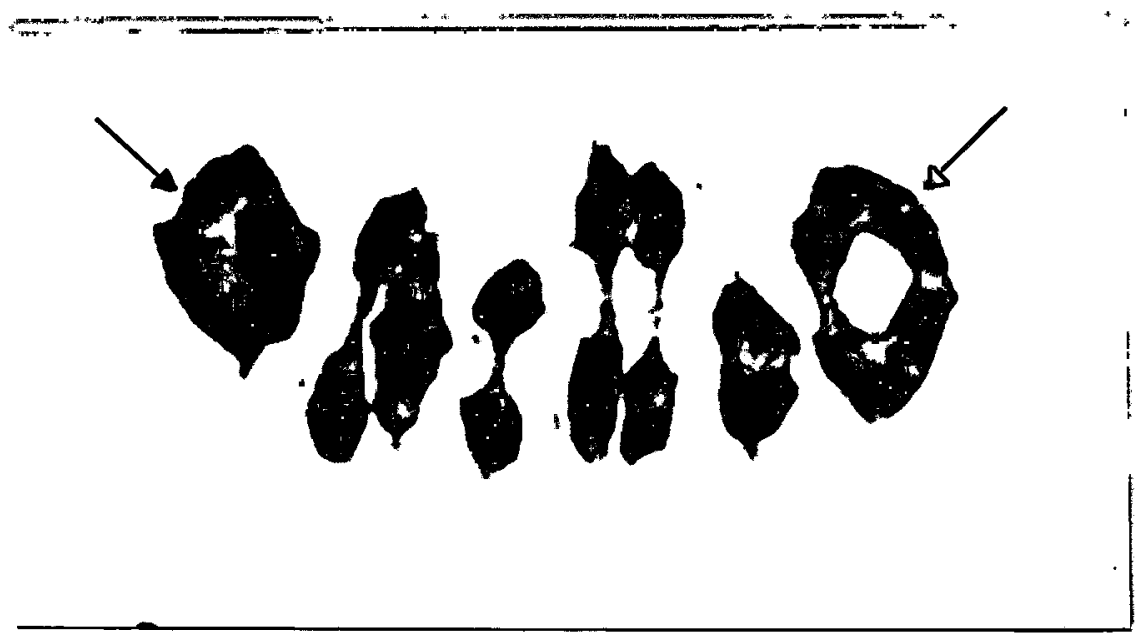

D. $\underline{\text { menziesii }}$

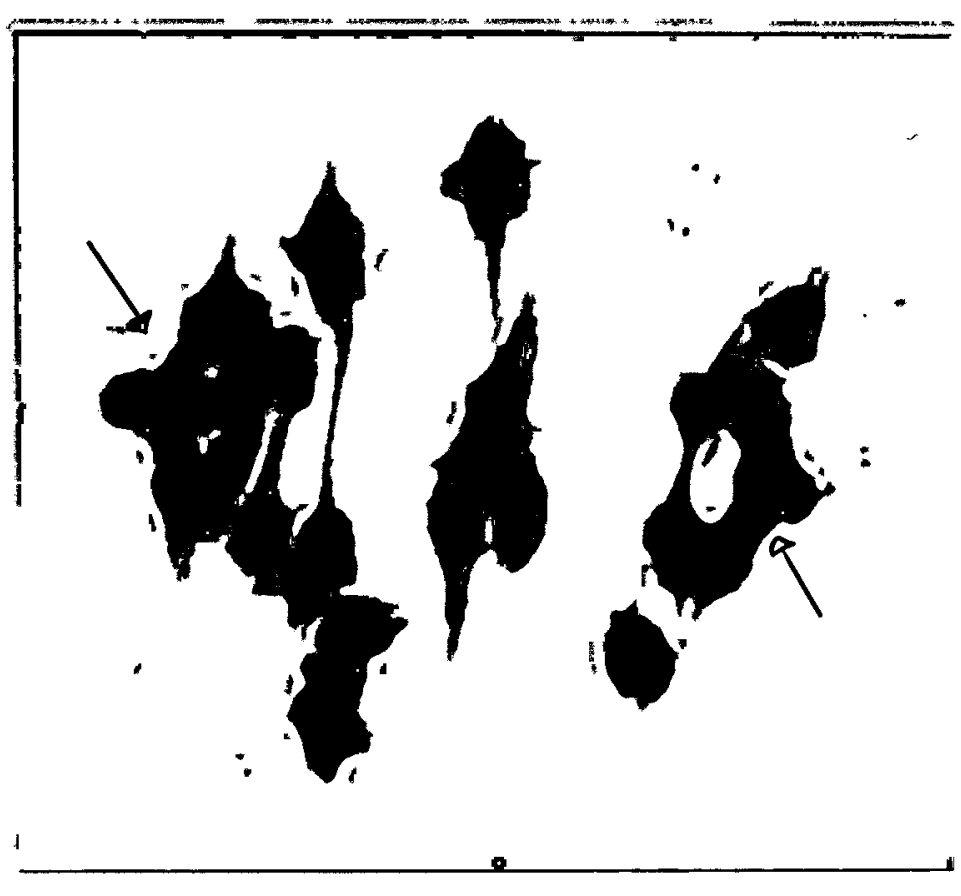

D. leucophaeum

Figure 14. Late metaphase $I$ in $\underline{D}$. menziesii and $\underline{D}$. leucophaeum. Open arrow is at bivalent 1 and closed arrow is at bivalent 2 in each cell. 


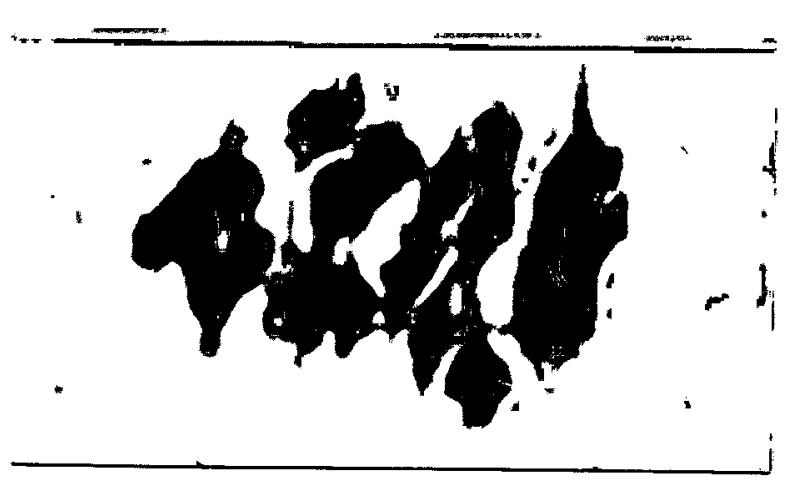

D. trolliifolium

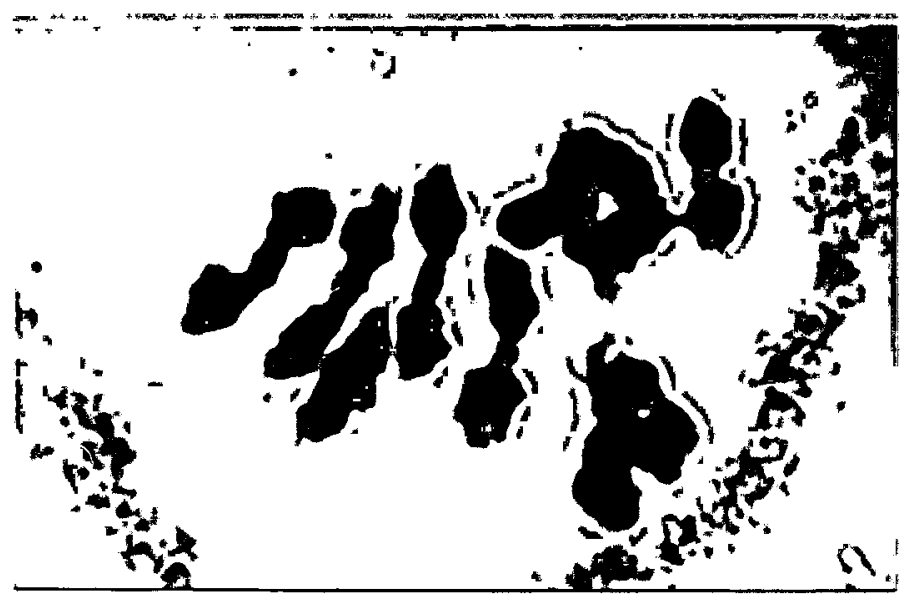

D. pavonaceum

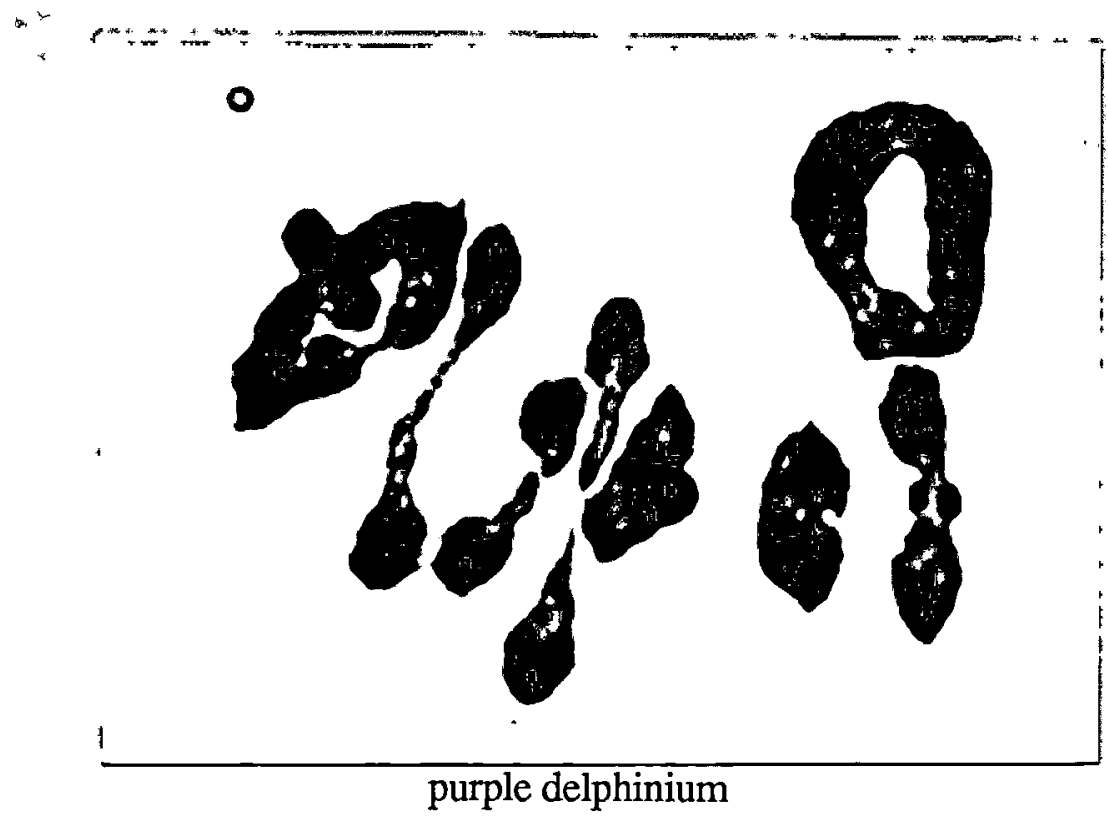

Figure 15. Late metaphase I in $\underline{\mathrm{D}}$. trolliifolium, $\underline{\mathrm{D}}$. pavonaceum and the purple delphinium. 
bivalent, since one crossover per bivalent is required for proper meiosis (Swanson 1981). The pairs appeared to have gone through normal synapsis and terminalization.

No anaphase bridges, fragments, lagging chromosomes, uni- or multivalents or other abnormalities indicative of structural heterozygosity were observed in any of these species, including the purple delphinium. Anaphase II resulted in four haploid microspores in all the Oregon species, as evidenced by the presence of a pollen tetrad, each cell of which contained eight chromosomes.

\section{REPRODUCTION}

Pollen Viability

Pollen grains in samples of anther contents from $\underline{D}$. pavonaceum, $\underline{D}$. trolliifolium and the purple delphinium were scored and high numbers of viable pollen grains were present in all three (Table V). Both $\underline{\mathrm{D}}$. pavonaceum and the purple delphinium produced upwards

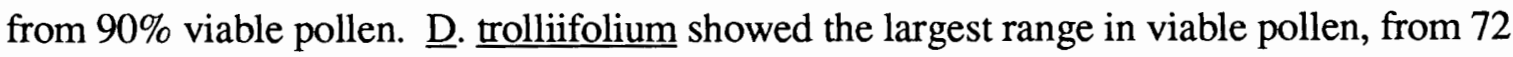
to $97 \%$.

Pollen tubes germinated from grains of all five Delphinium species. One pollen tube of D. leucophaeum contained two nuclei, possibly of the tube and generative cells.

\section{$\underline{\text { Seed/Ovule Ratios }}$}

Over the course of three springs, seed/ovule ratios of the five species in this study were calculated and compiled to give a three year average (Table VI). ‥ trolliifolium had the lowest average percent of seeds per ovule (61\%). D. leucophaeum had an average percent of 76 and the average seed production of $\underline{D}$. menziesii was $87 \%$. D. pavonaceum was nearly identical to $\underline{\mathrm{D}}$. menziesii in seed production (88\%). With $88 \%$ seeds per ovule, the purple delphinium appeared to be as reproductively active at this stage as the known species. 


\section{TABLE V}

\section{POLLEN VIABILITY IN THREE DELPHINIUM POPULATIONS}

\begin{tabular}{lcccc}
\hline \multicolumn{1}{c}{ Species } & $\begin{array}{c}\text { Number of } \\
\text { Plants }\end{array}$ & $\begin{array}{c}\text { Number of } \\
\text { counts }\end{array}$ & Average \% Viable & Range of \% Viable \\
\hline D. trolliifolium & 11 & 12 & 90.0 & $72.0-97.0$ \\
D. pavonaceum & 2 & 3 & 95.2 & $92.2-97.5$ \\
purple delphinium & 2 & 4 & 91.5 & $89.7-93.7$ \\
\hline Overall & 15 & 19 & 92.2 & $72.0-97.5$ \\
\hline
\end{tabular}

TABLE VI

SEED/OVULE RATIOS OF OREGON DELPHINIUMS

\begin{tabular}{lccc}
\hline Species & Average S/O & \% S/O & No. of Follicles \\
\hline D. trolliifolium & $13.0 / 21.3$ & 61 & 192 \\
D. menziesii & $16.1 / 18.6$ & 87 & 196 \\
D. pavonaceum & $16.3 / 18.6$ & 88 & 167 \\
D. leucophaeum & $10.3 / 13.5$ & 76 & 127 \\
purple delphinium & $19.6 / 22.2$ & 88 & 117 \\
\hline
\end{tabular}


Seed Germination

As shown in the left column of Table VII, large numbers of seeds in all the species in question germinated under appropriate cool, wet conditions, averaging $90 \%$ germination overall when stored at $6{ }^{\circ} \mathrm{C}$ for three months. Averages of seeds set up for germination throughout the year ranged from $77 \%$ to $96 \%$. $\underline{\text { D pavonaceum }}$ and the purple delphinium were highly productive with an average germination percent of 96 and 95 respectively. D. menziesii and D. trolliifolium radicles were also abundant, averaging $91 \%$ and $90 \%$ respectively. Although $\underline{D}$. leucophaeum seeds germinated more readily than those of the other species, its average of $77 \%$ is considerably lower than that of the others.

\section{SEED GERMINATION TECHNIQUE}

The exposure of seeds to various conditions confirms that seeds of the species in this study require an extended cool, wet period in order to germinate. The average percent germination for each Oregon Delphinium species over a nine month period is shown in Table VII. The placement of seeds in a moist, sterile environment at $6{ }^{\circ} \mathrm{C}$ for approximately three months guarantees high numbers of emerging radicles. Consistently high numbers of seeds left at $6^{\circ} \mathrm{C}$ germinated within approximately three months. Percentages ranged from $77 \%$ to $96 \%$ for the five species with an overall average of $90 \%$.

Germination did not occur at 12 and $22^{\circ} \mathrm{C}$, even when those seeds had first been chilled at $6{ }^{\circ} \mathrm{C}$ for up to five weeks. Seeds left at 12 or $22^{\circ} \mathrm{C}$ eight months or longer failed to germinate, even when mold or desiccation was not present. The only exception to this negative response was the discovery of four germinated seeds of $\underline{D}$. leucophaeum that had been left at $12{ }^{\circ} \mathrm{C}$ for several months. Seeds of all five species left at $12{ }^{\circ} \mathrm{C}$ for four months and then moved to $6^{\circ} \mathrm{C}$ germinated three months after the move.

Seeds left outdoors in autumn began to germinate three months later in January in spite of sub-freezing conditions. Temperatures were below freezing for twelve days in 
December including eight consecutive days when the thermometer stayed between approximately $-13{ }^{\circ} \mathrm{C}$ and $-4{ }^{\circ} \mathrm{C}$. Seeds of three species may have been adversely affected by the cold temperatures. Germination percentages for $\underline{\mathrm{D}}$. trolliifolium and $\underline{\mathrm{D}}$. menziesii were $42 \%$ and $52 \%$ respectively, approximately half of their optimum output when kept at a constant $6^{\circ} \mathrm{C}$. D. pavonaceum was also less productive; $75 \%$ of these seeds germinated in cold winter conditions as opposed to an average of $96 \%$ at $6{ }^{\circ} \mathrm{C}$. The productivity of D. leucophaeum and the purple delphinium seem unaffected by the sub-freezing temperatures, with $90 \%$ of their seeds producing radicles.

Comparisons of those seeds in the cold winter temperatures of 1990 - 1991 as opposed to those outdoors during the warmer winter of 1991 - 1992 indicate possible differences in response to cold among some species (Table VIII). The cold winter germination level of D. trolliifolium was $42 \%$ as opposed to $11 \%$ during the warmer winter. Similarly, germination percentages of $\underline{\mathrm{D}}$. menziesii and $\underline{\mathrm{D}}$. pavonaceum decreased from 52 to 24 and 75 to 50 , respectively. ‥ leucophaeum and the purple delphinium may have been unaffected or even aided by the warmer winter. Both show $90 \%$ during the cold winter and $100 \%$ during the warm one.

Throughout one year, seeds placed in wet Petri dishes and left at $6{ }^{\circ} \mathrm{C}$ consistently produced high numbers of radicles. Regardless of the set up date, each batch of seeds took approximately 70 to 90 days for germination to begin. Once germination began, radicles emerged over a period of four to eight weeks, each radicle reaching optimum length for mitotic studies about one week after emergence.

The minimum length of dormancy from follicle dehiscence to radicle emergence at $6{ }^{\circ} \mathrm{C}$ is three months. This period includes the required cool wet period prior to exposure to proper germination conditions. Cold storage of dry seeds can extend the period of dormancy to at least 2.5 years; seeds collected in 1989 and stored at $6{ }^{\circ} \mathrm{C}$ were placed in wet Petri dishes at $6^{\circ} \mathrm{C}$ in July 1991 and began to germinate three months later. 
TABLE VII

PERCENT SEED GERMINATION AT $6^{\circ} \mathrm{C}, 12^{\circ} \mathrm{C}$ AND

AMBIENT SUB-FREEZING WINTER

\begin{tabular}{|c|c|c|c|c|c|c|}
\hline \multirow[b]{2}{*}{ Species } & \multicolumn{2}{|c|}{$6^{\circ} \mathrm{C}$} & \multicolumn{2}{|c|}{ Cold Winter } & \multicolumn{2}{|c|}{$12^{\circ} \mathrm{C}$} \\
\hline & $\%$ & $\bar{N}$ & $\%$ & $\bar{N}$ & $\%$ & $\mathrm{~N}$ \\
\hline D. trolliifolium & 90 & 3936 & 42 & 967 & 0 & 1366 \\
\hline D. menziesii & 91 & 5494 & 52 & 753 & 0 & 920 \\
\hline D. pavonaceum & 96 & 6115 & 75 & 2030 & 0 & 748 \\
\hline D. leucophaeum & 77 & 1366 & 90 & $400^{1}$ & 0.67 & $600^{1}$ \\
\hline purple delphinium & 95 & 2633 & 90 & 1138 & 0 & 1229 \\
\hline average $\%$, total $\mathrm{N}$ & 90 & 19544 & $\overline{70}$ & 5288 & 0.67 & 4863 \\
\hline
\end{tabular}

TABLE VIII

PERCENT SEED GERMINATION IN SUB-FREEZING WINTER VS WARM WINTER

\begin{tabular}{lcccc}
\hline \multicolumn{1}{c}{ Species } & \multicolumn{2}{c}{ Cold Winter } & \multicolumn{2}{c}{ Warm Winter } \\
\cline { 2 - 5 } & $\%$ & $\mathrm{~N}$ & $\%$ & $\mathrm{~N}$ \\
D. troliifolium & 42 & 967 & 11 & 150 \\
$\underline{\text { D. menziesii }}$ & 52 & 753 & 24 & 300 \\
D. pavonaceum & 75 & 2030 & 50 & 150 \\
D. leucophaeum & 90 & 400 & 100 & 300 \\
purple delphinium & 90 & 1138 & 100 & 300 \\
average \%, total N & 70 & 5288 & 57 & 1200 \\
\hline Note: $\mathrm{N}=$ number of seeds scored & & &
\end{tabular}




\section{TISSUE CULTURE}

\section{Resulting Structures}

Callus growth was characteristic of in vitro cultures from the various explants. Most flower buds, stem segments, leaf sections or bases, shoot tips, seedlings with corms and seedling shoots developed calluses to some degree. Hormone ratios most often associated with callus development were $1.00: 1.00$ and $1.00: 0.03^{1}$. All species but $\underline{D}$. menziesii, which was not cultured, produced calluses. Calluses contained a mixture of large, thinwalled cells and typical undifferentiated cells containing interphase or rare mitotic nuclei.

Roots occasionally developed from the various types of explants. Although a callus or other intermediate growth characterized these cultures, roots were also seen growing directly from the explants. Hormone ratios contributing most to root development were $1.00: 1.00$ and $1.00: 0.00$. One tube containing media without hormones resulted in root formation. No particular ratio of hormones led solely to the production of roots directly from explant tissue. In many cases, vascular cells were also present. Metaphase nuclei were observed in several cells of younger roots.

Plant-like structures developed in some cases, manifesting thick stems with short branches and leaves. The only roots present were those growing from the calluses that were attached to these structures. The structures developed from shoot tips, flower buds and leaf bases taken from $\underline{D}$. pavonaceum and $\underline{D}$. leucophaeum and placed in media containing hormone ratios of $1.00: 0.00$ or $1.00: 1.00$.

Original flower buds, leaves and stems also grew larger in culture without developing into other structures. This typically occurred in a medium without hormones.

Leaves developed from each of the various explants mentioned either without hormones or in media consisting of hormones in a $1.00: 0.00$ ratio.

1 (mg/L napthaleneacetic acid : benzyladenine; auxin : cytokinin); pertains to all hormone ratios in thesis 
Abnormal structures such as horns and knobs grew from flower bud explants, often via a callus stage in media containing a hormone ratio of $1.00: 1.00$. The cytology of these structures included vascular cells, large, enucleate finger-shaped cells and other unidentifiable cells.

\section{Chromosomes from Cultured Tissues}

A search for metaphase chromosomes among products of tissue culture such as calluses, shoot tips, root tips and leaves revealed low numbers of mitotic cells in some roots and calluses of $\underline{\mathrm{D}}$. pavonaceum, $\underline{\mathrm{D}}$. leucophaeum and $\underline{\mathrm{D}}$. trolliifolium. Occasionally, chromosomes of analyzable quality (well spread with good resolution) were seen, but in most cases, chromosome spreads were of poor quality. Polyploid cells were occasionally seen mixed in with diploid cells.

Comparisons of overall ploidy levels in calluses and roots that developed in vitro in three species are detailed in Table IX. Due to poor chromosome quality, only distinctions between diploid and higher ploidy were made; the number of sets of chromosomes higher than two was not discernable. These tissues were pretreated for three hours in $0.1 \%(w / v)$ colchicine to increase the mitotic index. With some exceptions, calluses had a higher ratio of polyploid to diploid cells than did roots. In calluses, out of a total of 51 cells, 33 were diploid and 18 polyploid, nearly a $2: 1$ ratio of diploid to polyploid. In cultured roots, out of a total of 65 cells, 62 were diploid and 3 were polyploid, a ratio of $21: 1$. In cell preparations of six cultured $\underline{D}$. pavonaceum roots, a total of 58 diploid and no polyploid cells were seen. In general, a mixture of polyploid and diploid cells were present in either cultured roots or calluses of most samples.

A few cultured tissues that had not been treated with colchicine were examined. As seen in Table IX, nearly twice as many polyploid as diploid cells were observed in a total of 23 untreated callus cells. Only two diploid cells were seen in two untreated roots. 
TABLE IX

COMPARE PLOIDY IN CULTURED CALLUS VS ROOTS OF THREE SPECIES WITH COLCHICINE TREATED AND UNTREATED SAMPLES

\begin{tabular}{|c|c|c|c|c|c|c|c|}
\hline \multirow[t]{2}{*}{ Species } & \multirow[t]{2}{*}{ Tissue } & \multicolumn{3}{|c|}{ Colchicine } & \multicolumn{3}{|c|}{ No Colchicine } \\
\hline & & Organs & $\begin{array}{c}2 \mathrm{~N} \\
\text { Cells }\end{array}$ & $\begin{array}{c}\text { Polypl. } \\
\text { Cells }\end{array}$ & Organs & $\begin{array}{c}2 \mathrm{~N} \\
\text { Cells }\end{array}$ & $\begin{array}{l}\text { Polypl. } \\
\text { Cells }\end{array}$ \\
\hline \multirow[t]{2}{*}{ D. trolliifolium } & callus & 3 & 2 & 9 & 1 & 2 & 6 \\
\hline & roots & 3 & 0 & 0 & 0 & $\ldots$ & $\cdots$ \\
\hline \multirow[t]{2}{*}{ D. pavonaceum } & callus & 3 & 16 & 3 & 1 & 0 & 2 \\
\hline & roots & 6 & 58 & 0 & 0 & $\cdots$ & . \\
\hline \multirow[t]{2}{*}{ D. leucophaeum } & callus & 4 & 15 & 6 & 3 & 6 & 7 \\
\hline & roots & 1 & 4 & 3 & 2 & 2 & 0 \\
\hline \multirow[t]{2}{*}{ Total } & callus & $\overline{10}$ & $\overline{33}$ & 18 & 5 & 8 & 15 \\
\hline & roots & 10 & 62 & 3 & 2 & 2 & 0 \\
\hline
\end{tabular}


Other chromosome abnormalities common in cultured tissues such as aneuploidy, breaks and translocations were not observed. They may be present, however, because poor metaphase resolution in several cases made even ploidy impossible to determine.

In view of the fact that cultured roots have more diploid cells than calluses and that these cells are likely more genetically stable, an attempt was made to determine the best source tissue for root development. Some but not all seedling shoots, shoot tips, flower buds, leaf bases, leaves and stem segments in media of various hormone concentrations yielded roots. Most cultured roots were secondary growths on callus or leaves that developed from the parent tissues. Flower buds, leaves and shoot tips were the most favorable explants. Most roots developed in media containing hormones in $1.00: 1.00$ or $1.00: 0.00$ ratios of auxin to cytokinin. 


\section{DISCUSSION}

\section{CYTOGENETICS}

A common type of karyotype analysis involves chromosome number, measurement, centromere location and gross chromosome morphology, such as satellited or heteromorphic chromosomes (White 1963). This is the analytical approach employed here. Certain limitations do exist at this level of analysis. For example, technique, as well as aspects of chromosome structure may influence the accuracy of chromosome measurements and satellite counts. Different exposures to colchicine can influence the degree of DNA condensation and hence chromosome length (Darlington and LaCour 1976). Length is also influenced by differential condensation of DNA due to the stage of the cell cycle when fixation occurred and by gene activity during the previous interphase (Heslop-Harrison et al. 1988). Variations in length due to any of these factors may be confused with actual structural differences among species. Artificial differences in arm length and hence ratio may also interfere with accurate chromosome identification which is of particular importance when assignment of satellites is involved. Karyotypes may differ in size and shape between developmental stage or tissue; roots may not represent the rest of the plant (Dyer 1979).

Although the number of satellites and their chromosomal location may be useful in distinguishing species, this information must be interpreted with reservation. Inconsistent numbers of satellites within individuals and species are often reported. This may be due to artificial or real factors. Satellites may be hidden by the remainder of the chromosome or missing due to chromosome (stalk) breakage while squashing (Dyer 1979). Reed and Burns (1987) suggested that colchicine pretreatment may condense chromosomes to the 
point where the secondary constriction is too short to be distinguished and the concurrent satellite is therefore not visible as such. Jamilena (1990) found that a reduction or absence of ribosomal DNA or an inactive nucleolar organizing region (NOR) may also prevent the formation of a secondary constriction and thus observation of satellites. These last two features are considered to be consistent within an individual but not necessarily a species (Babu and Verma 1987). In addition to these variables, orcein stained chromosomes in group B of the Delphinium genome are indistinguishable. This adds another dimension of uncertainty in assigning satellites to particular chromosomes and therefore influences any conclusions made regarding satellite distributions.

The following steps were taken to compensate for potential inaccuracies inherent in chromosome analysis: 1) an attempt was made to minimize the subjective nature of choosing and measuring chromosomes by using only cells at mid-metaphase for analysis; no pro-metaphase or overly condensed chromosomes were measured;2) to minimize artificial differences among cells, measurements from ten cells per species were averaged; 3) cells from shoot tips were examined and no differences in chromosome number or size were apparent when compared with cells of seed radicles; and 4) satellite numbers and their possible chromosomal positions from ten cells per species were recorded in order to ascertain the extent of intraspecific differences (real and/or imaginary) and the number of satellites visible in single cells was noted.

\section{$\underline{\text { Mitosis }}$}

Until the connection between chromosomes and genes was karyologically verified by Bridges in 1914 (Suzuki et al. 1989), cytology focused on chromosome alterations during the cell cycle such as changes in behavior and degree of condensation; chromosome morphology and number were of secondary importance. Consequently, in the 1890's and early 1900 's, inaccurate chromosome numbers of many angiosperm species, including 
Delphinium, were reported. It was not until 1926 that the haploid number for the first three species examined, $\underline{\text { D. ajacis, }}$ D. nudicaule and $\underline{\text { D. }}$ consolida (now placed in the genus Consolida), was changed from 12 to 8 by Tjebbes (1927). His description of chromosome morphology during microsporogenesis is in general agreement with more recent reports on other Delphinium species. Confirmation of chromosome number came from Ewan (1945), who reported that nine Old World and six New World Delphinium species were polyploid with a basic number of eight.

An interest in the origin of cultivated polyploid delphiniums led Lawrence (1935) to summarize the current knowledge for 11 diploids, 6 tetraploids and 1 hexaploid cultivar (a naturally doubled triploid hybrid). With the exception of one species, chromosome morphology was shown to be similar to that of other Delphinium species. His is the first report of allopolyploidy in this genus.

More recent chromosome counts of Delphinium species from different parts of the world describe a typically diploid genome with a haploid number of eight. In a study of both wild and unspecified cultivars from unidentified locations, Legro (1961) concluded that only diploids are found in the field and that the tetraploid and hexaploid cultivars he saw were the result of long periods under cultivation or artificial interspecific crosses. In contrast, Lewis et al. (1951) found natural polyploids, particularly allotetraploids, occurring within diploid populations of some California species. A few triploid hybrids were also encountered. Al-Kelidar and Richards (1981) found entirely tetraploid populations of some North American species, including one from California.

A list of Delphinium species that have been cytologically investigated is in Appendix C. As yet, no banding of any Delphinium chromosomes has been reported.

The Oregon Delphinium species are diploid $2 n=16$, consistent with accounts of other delphiniums (Legro 1961; Lewis et al. 1951; Tjebbes 1927). The even number of chromosomes and the presence of morphologically distinct homologous pairs are evidence 
of diploidy. The absence of polyploid individuals contrasts with other reports of tetraploid Delphinium species (Al-Kelidar and Richards 1981) and diploid species containing tetraploid and triploid populations (Lewis et al. 1951). A general trend from diploidy to polyploidy among individual plant species has been noted (Stebbins 1971). The older the species, the more likely it contains populations and/or individuals within populations with more than two sets of chromosomes. This correlation with ploidy level and age suggests that the diploid populations of Oregon Delphinium species may be newer than those outside of Oregon that contain polyploid individuals.

Identical in number and similar in size and shape, the karyotypes of these Oregon Delphinium species support and extend previous observations of Lewis et al. (1951) and Stebbins (1971) that delphiniums are a chromosomally homogeneous group. The basic similarity in chromosome length, arm ratio and relative length among the karyotypes of these Oregon species suggests that either little chromosome evolution has occurred during their divergence or that it has been parallel in nature. A third possibility is that structural changes in chromosomes have occurred but are not observable without the application of banding techniques.

A pattern in chromosome lengths among the Oregon species was seen. Corresponding

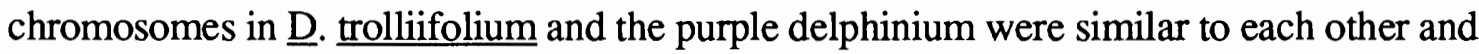
less similar to those of the other three species (Table III). This may indicate that D. trolliifolium is one of the parental sources of the purple delphinium. Species with shorter chromosomes (e.g., D. menziesii) may reflect a loss of chromatin, suggesting that D. menziesii is a derived species (Al-Kelidar and Richards 1981). Alternatively, tandem duplications of chromosome segments may have occurred in the longer chromosomes of D. trolliifolium, in which case the chromosomes may have evolved from small to large. This suggests that $\underline{\mathrm{D}}$. trolliifolium is the derived species and $\underline{\mathrm{D}}$. menziesii is ancestral (Dyer 1979). Another possibility is that elevation, known to influence the amount of DNA per 
cell (Rayburn 1990), may have resulted in smaller chromosomes for the population of D. menziesii, studied here, found at approximately 1200 meters. There is a chance that patterns in length among species may be due to species specific responses to colchicine.

Statistical analyses of the chromosome measurements of the Oregon species revealed significant differences in the mean arm ratio and length of chromosome 2 and the mean arm ratio of chromosome 8. As shown in Figure 5, D. trollliifolium and the purple delphinium are more similar to each other than to $\underline{D}$. menziesii, $\underline{D}$. leucophaeum and/or $\underline{\mathrm{D}}$. pavonaceum for these three values. This suggests that $\underline{D}$. trollliifolium and the purple delphinium are more closely related to each other than they are to the other three species and vice versa. It has been proposed that $\underline{\mathrm{D}}$. leucophaeum is derived from crosses between $\underline{\mathrm{D}}$. pavonaceum and $\underline{\mathrm{D}}$. menziesii (Oregon Natural Heritage Program, personal communication 1990) or that $\underline{D}$. pavonaceum is derived from $\underline{D}$. menziesii $x \underline{D}$. leucophaeum (Ewan 1945). The statistical analysis supports either of these proposals.

In the one literature report that included measurements, $\mathrm{Al}$-Kelidar and Richards (1981) found that the range in chromosome lengths among Delphinium species from various parts of the world varied from 9 to 3 micrometers in the largest genome to 6 to 1.5 micrometers in the smallest. He concluded that ancestral species had larger chromosomes and that the derived forms were due to breakage and fragment loss. Ranging in average length from 2.5 micrometers (chromosome 8) to 10.1 micrometers (chromosome 1), the chromosomes of the of the Oregon species are similar in overall length to those Al-Kelidar and Richards measured.

Chromosome morphology was found by Lewis et al. (1951) to be similar among native California species. This similarity was later found by Legro (1961) to extend beyond California to include North America and Europe. He concluded that the karyotype of the California species was representative of North American Delphinium. 
The idiogram in Figure 16 represents a haploid composite karyotype of seven California species ${ }^{2}$ (Lewis et al. 1951). There are two long chromosomes, one metacentric and the other submetacentric. Four chromosomes of intermediate length and two slightly shorter ones make up the rest of the genome. All but the smallest of these are subtelocentric. The smallest chromosome is submetacentric. A satellite is found on one subtelocentric chromosome.

A vague description of a cultivar of the European $\underline{D}$. ajacis is basically similar to that of the California species mentioned above. It has eight chromosomes, two long ones with nearly median centromeres and six shorter ones with subterminal primary constrictions (Jain and Basak 1963).

The chromosomes of the California species resemble those of the Oregon species. Both genomes are asymmetric with two long and six shorter chromosomes. Centromere positions are in rough correspondence. In both cases all but chromosomes 1,2 and 8 are subtelocentric. Minor differences are also apparent. The arm ratios of the subtelocentric chromosomes in the California species are greater than those of the Oregon group. The centromere of chromosome 2 is nearly median in the California species and is submedian in the Oregon delphiniums. The relative chromosome lengths of the California species also differ from the average relative lengths of the Oregon species (Table X). Although Lewis found chromosomes 3, 4 and 5 difficult to distinguish, they were labelled individually, perhaps misleadingly so.

Differences in chromosome lengths and arm ratios between the Oregon and California species may be partly due to differences in technique. They may also be evidence of chromosome evolution. Stebbins (1971) concluded that variations in arm ratios and lengths are to be expected in species whose structural differentiation is the result of

${ }^{2} \underline{\mathrm{D}} . \underline{\text { hanseni, }} \underline{\mathrm{D}}$. parishii, $\underline{\mathrm{D}}$. parryi, $\underline{\mathrm{D}}$. hesperium, $\underline{\text { D. recurvatum. }}$ D. variegatum, D. gypsophilum 


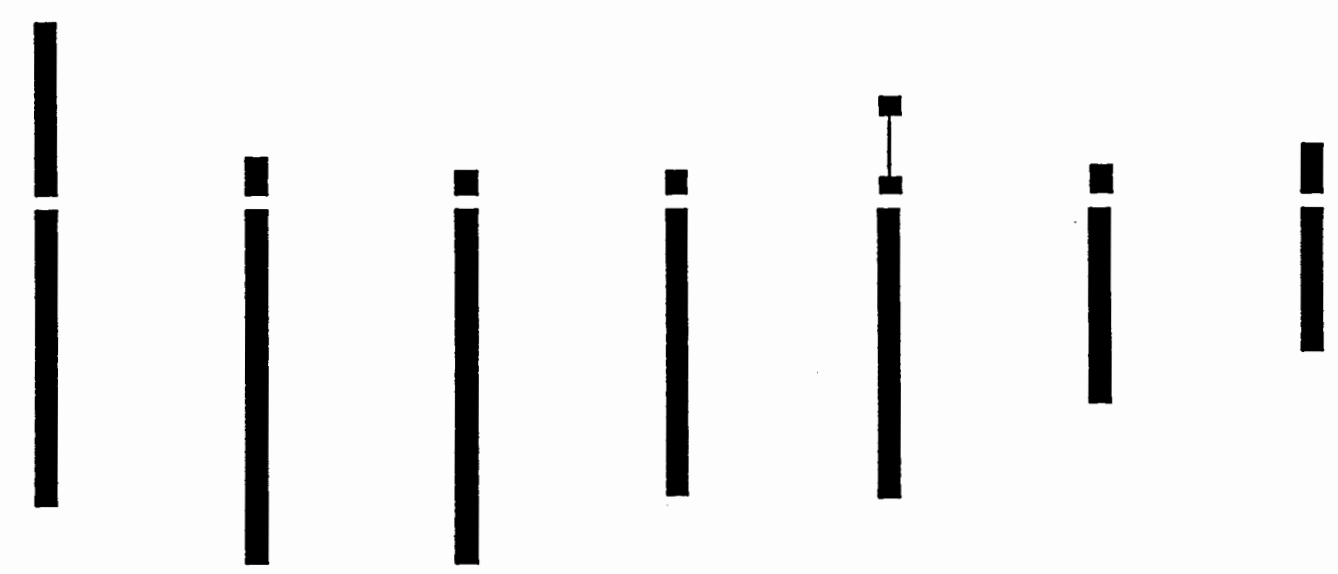

\footnotetext{
bar $=1 \mu \mathrm{m}$
}

Figure 16. Composite idiogram of seven California Delphinium species. Redrawn from Lewis 1951. 
TABLE $\mathbf{X}$

COMPARE ARM RATIOS AND RELATIVE LENGTHS BETWEEN OREGON AND CALIFORNIA DELPHINIUMS

\begin{tabular}{clcc}
\hline Chrom. No. & \multicolumn{1}{c}{ Value } & Oregon & California \\
\hline \multirow{2}{*}{1} & ratio & 1.2 & 1.0 \\
& relative length & 24.4 & 20.6 \\
2 & ratio & 2.0 & 1.7 \\
& relative length & 20.6 & 16.3 \\
Group B & ratio & 4.7 & 9.0 \\
& relative length & 10.6 & 13.7 \\
Group B & ratio & 4.7 & 13.5 \\
& relative length & 10.1 & 13.3 \\
Group B & ratio & 4.9 & 11.0 \\
& relative length & 9.6 & 10.9 \\
Group B & ratio & 4.7 & 22.0 \\
& relative length & 9.3 & 10.5 \\
\multirow{2}{*}{7} & ratio & 4.0 & 7.5 \\
& relative length & 8.6 & 7.7 \\
\multirow{2}{*}{8} & ratio & 2.9 & 2.6 \\
& relative length & 6.7 & 6.9 \\
\hline
\end{tabular}

Note: arm ratio $=$ long arm divided by short arm $(\mathrm{L} / \mathrm{S})$

relative length $(\%)=$ chromosome length divided by total genome length $\times 100$ 
mutations such as pericentric inversions, unequal translocations and deletions. Karyotype similarity may be a reflection of similar genomes (Hsiao 1986). The fact that a greater karyotype similarity exists among the Oregon species than between them and those of California suggests that these Oregon species are more closely related to one another than they are to California species.

More obvious differences in chromosome morphology have been reported. For example, Lawrence (1935) found that $\underline{\mathrm{D}}$. cardiopetalum has only one pair of submetacentric chromosomes and seven pairs of subtelocentric chromosomes. According to Mehlquist et al. (1943), the karyotype of $\underline{D}$. cardinale can be distinguished by the presence of nearly terminal centromeres on the two smallest chromosomes.

A study by Al-Kelidar and Richards (1981) that includes Delphinium species from several parts of the globe illustrates considerably more variety in sizes and arm ratios than generally seen among largely North American species, however, his inconsistent presentation of data leaves some doubt as to the accuracy of the results. He correlated karyotypes with evolutionary relationships, finding 20 morphologically distinct chromosomes distributed among 13 Delphinium species. Satellites were observed in five species and varied from one to two per cell. Although satellites were assigned to particular chromosomes, chromosome identification was not precise, therefore leaving his designation of satellited chromosomes in question. However, even if only partially correct, this karyotype variability among some Delphinium species is evidence of chromosome evolution not seen by other investigators.

The number of visible satellites and their chromosomal locations vary from cell to cell within and among the Oregon species. However, the record of ten cells from each species shows that at least four nonhomologous satellited chromosomes are present in the haploid set of all but $\underline{\mathrm{D}}$. leucophaeum, within which three were verified. It may be that there is no difference in satellite number or position among these species, results that are consistent 
with other observations of chromosome homogeneity in this Oregon group of delphiniums. The lack of homologue validation in group B prevents the identification of parental chromosomes in the purple delphinium based on satellite position. However, the data do not exclude any of the candidate parent species proposed by Goodrich (1985): D. pavonaceum, $\underline{\mathrm{D}}$. trolliifolium or $\underline{\mathrm{D}}$. menziesii.

Satellite numbers in Oregon species exceed the single satellite present in some California species (Lewis et al. 1951) and the maximum number of two satellites reported in a study that includes European and Asian species (Al-Kelidar and Richards 1981). The high number of satellites in the Oregon species is unusual according to Stebbins (1971), who considers it rare to find greater than two pairs of satellited chromosomes in angiosperms.

Close associations of the short arms (and often including the long arms) of several of the smaller chromosomes were observed in the majority of cells in each of the five species. Non-homologous chromosomes were often associated. One or two groups of two, three and occasionally more chromosomes could be seen within a single cell. Satellites were often seen in the area of chromosome association. The NOR is adjacent to satellites in most species (Reed and Burns 1987) and this is likely the case here. However, there are exceptional species in which this is not so. For example, in rare cases the NOR is terminal or centromeric, and no secondary constriction is present (Reed and Burns 1987). Conversely, it has been noted that some secondary constrictions are not sites of NORs but rather sites of constitutive heterochromatin (Comings 1972 as cited in Weimarck 1981). But, the fact that these Delphinium chromosomes are closely associated in the regions of their satellites is evidence of NOR involvement; fusion of nucleoli earlier in the cell cycle often results in this type of association (Reed and Burns 1987). No such associations have been mentioned in other reports on Delphinium karyotypes (Al-Kelidar and Richards 1981; Legro 1961; Lewis et al. 1951). 
A concern is that chromosome associations are the result of colchicine pretreatment and not real. In a recent study by Morais et al. (1991) of the effects of colchicine on wheat and rye chromosomes it was concluded that the increase in concentration and/or period of exposure of colchicine can produce abnormal metaphases consisting entirely of one or two groups of tightly associated chromosomes. It was suggested that this was due to factors other than spindle malfunction, such as the dissolution of the nuclear membrane or chromatin attachment during late interphase and early metaphase. In this case, colchicine is not a factor since no cells containing only two large groups of chromosomes were seen in Delphinium cells. Chromosomes were well spread with the exception of one or two and occasionally three groups of usually two or three subtelocentric chromosomes.

Cells of one $\underline{D}$. trolliifolium seed radicle contained two unmatched sets of chromosomes, one of which is clearly dissimilar to known Delphinium karyotypes. This is likely the result of intergeneric hybridization, a possibility mentioned by Epling and Lewis

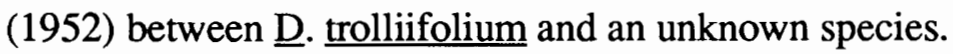

\section{$\underline{\text { Meiosis }}$}

The early work of Tjebbes (1927) on the meiosis of $\underline{D}$. ajacis and $\underline{D}$. nudicaule shows eight bivalents, two large ring-like or U-shaped bivalents and six smaller rod bivalents during metaphase I. Later studies confirm Tjebbes' description and include observations of chiasmata (Lewis et al. 1951; Jain and Basak 1963).

Of the few meiotic studies of this genus, only two pursue the subject in any detail. One analysis of 12 California species (nine diploids and three tetraploids) by Lewis et al. (1951) describes eight bivalents in the diploids (Figure 17). The two longer pairs of chromosomes usually have one chiasma per arm. Occasionally, a second chiasma can be seen on the long arm of bivalent 1. Each of the other six shorter bivalents have one chiasma in the long arm. By metaphase I, terminalization of the chiasmata is usually complete in the six shorter 
bivalents but not in the two larger chromosome pairs. This gives the appearance of two open rings and six rods.

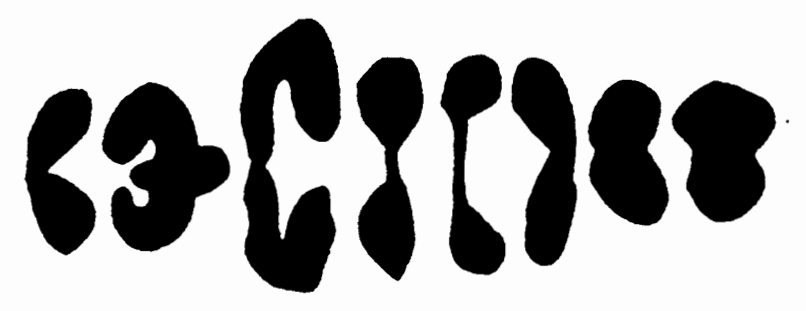

Figure 17. Late metaphase I in $\underline{D}$. parishii, a California species. Redrawn from Lewis et al. 1951.

Abnormalities have been noted in some California delphiniums: an anaphase I bridge and fragment was found in $22 \%$ of the diploid plants, suggesting possible inversion heterozygosity and evidence of current interspecific hybridization. Frequent quadrivalents appeared in the tetraploids with the two longer chromosomes forming a ring or chain of four, occasionally followed by unequal segregation (Lewis et al. 1951). This was in contrast to a study of colchicine induced tetraploids in which multivalents were rare (Mehlquist et al. 1943). This is evidence of natural allopolyploidy in this genus.

A study of six diploid Delphinium species describes a meiosis with no irregularities, the two longer pairs of chromosomes forming ring bivalents and occasionally a third, shorter pair also. Pachytene analysis is reported to be difficult and information is not available on the extent of pairing, an indicator of chromosome homology (Legro 1961). Another report of meiosis in a cultivar of $\underline{D}$. ajacis agrees with the above description (Jain and Basak 1963).

Chromosome configurations (two ring and six rod bivalents) during metaphase I and early anaphase I are similar among the Oregon species and also when compared with other Delphinium species, further evidence of chromosome homogeneity in this genus. 
Chromosome structural differences that are not apparent during mitosis may be visible at metaphase and anaphase of meiosis I (Dyer 1979). The presence of eight bivalents and the absence of chromosome bridges or other abnormalities in metaphase I are evidence of structurally homozygous chromosomes in each of the Oregon species. Evidence of introgression in the form of structural heterozygosity is lacking.

The location and number of apparent chiasmata in the Oregon species agree with other accounts. Chiasmata form during prophase I and terminalize during late metaphase and early anaphase. Since prophase was not analyzed, accurate accounts of chiasmata are not available. However, this is not critical since it is known that the number of chiasmata can vary both among and within Delphinium species (Basak and Jain 1964).

Chromosome counts at late anaphase II in the Oregon species and the purple delphinium show eight per cell, the expected gametic number.

\section{Hybrid Issue}

Although self-compatible, outcrossing is the usual mode of reproduction in Delphinium. They attract bumblebees, several species of which serve as major pollinators (Epling and Lewis 1952). Hummingbirds have also been seen pollinating some species (Guerrant 1982).

The stamens of delphiniums release pollen before the stigma of the same flower is receptive. This protandrous condition, along with the habit of bumblebees to move from lower, older flowers to younger ones higher on the raceme, encourages cross-pollination. Apomixis has not been observed in this genus. Interplant pollination generally occurs within a small area (Epling and Lewis 1952), although it has been suggested that the bees can fly several miles between populations and that pollen may on rare occasion be transferred long distance by bees (Santana 1975). The exact mechanisms of seed dispersal are unknown but there is evidence that, although they fall predominately within one or two 
meters of the parent plant, strong winds or animals may carry them further (Epling and Lewis 1952).

Lack of water is the main factor in maintaining dormancy and, in turn, is necessary, along with proper temperatures, for ending it. Seeds and corms are known to remain dormant for up to ten years when conditions are too stressful for germination or development. At any stage of growth, if the narrow range of conditions for germination is not met, the plants return to a dormant state where only the corms remain alive. This can give the appearance of distinct populations that may, in fact, be a single population (Epling and Lewis 1952 ).

Delphiniums display several qualifications for the formation of stable hybrid populations that may occasionally form new species. Mating dynamics make hybridization possible. Pollinating bees are not species specific in their choice of flowers to visit. Contiguous, overlapping or composite populations of separate species exist. They are within pollinating range of one another and, if blooming periods overlap, hybridization is possible. Genetic similarity removes another barrier against successful hybrid reproduction (Lewis and Epling 1959). Environment can also contribute to interspecific mating; species of different blooming times have been known to flower simultaneously with unusual weather (Warnock 1987).

Lewis and Epling (1959) suggested that the formation of a species of hybrid origin in California relied upon its capacity for an extended dormancy. It was thought that the hybrid's genotype was not adaptive to the environmental conditions under which its parents flourished and that its seeds remained dormant until conditions changed. They concluded that the principle means of speciation in this genus is not via introgression nor polyploidy, but rather through exposure of a hybrid to favorable habitat. Epling and Lewis (1952) proposed that hybrid seeds may also be moved to another habitat more suitable to the hybrid phenotype. 
Lewis (1946) found tetraploid individuals within diploid populations of California delphiniums, which led to his discovery of diploid, triploid and tetraploid hybrids. However, no evidence of introgression was found.

Lewis and Epling (1959) crossed $\underline{\text {. }}$ hesperium with $\underline{\mathrm{D}}$. recurvatum and analysed meiosis in the hybrid progeny. In this case, evidence of introgression was found. The hybrid was shown to be heterozygous for two paracentric inversions and a reciprocal translocation between chromosomes 1 and 2 . In this case, structurally heterozygous chromosomes of $\underline{\mathrm{D}}$. hesperium, possibly due to introgression by $\underline{\mathrm{D}}$. variegatum, significantly reduced the fertility of the hybrid. However, the naturally occurring hybrid of these two species is fertile with no evidence of structural heterozygosity. It is found in relative abundance, overlapping with populations of its parent species.

Santana (1975) found evidence of an introgressive hybrid, likely the product of $\underline{\mathrm{D}}$. trolliifolium and $\underline{\mathrm{D}}$. nudicaule, with $\underline{\mathrm{D}}$. trolliifolium as the recurrent parent.

Goodrich (1985) recently proposed that the purple delphinium in Oregon is of hybrid origin. A population of this purple delphinium is sympatric with $\underline{D}$. pavonaceum and although its sepal color differs, it is morphologically indistinct from $\underline{D}$. pavonaceum. The purple delphinium could be a color variation of $\underline{\mathrm{D}}$. pavonaceum or perhaps the ancestral species from which $\underline{\mathrm{D}}$. pavonaceum is derived. Another explanation is that it may be an introgressive hybrid between $\underline{\mathrm{D}}$. pavonaceum and some other plant with purple sepals,

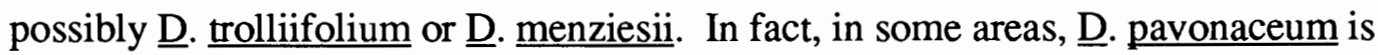
sympatric with $\underline{\mathrm{D}}$. menziesii and contiguous with $\underline{\mathrm{D}}$. trolliifolium. If hybrid in origin, the degree of morphological similarity between the purple delphinium and $\underline{\mathrm{D}}$. pavonaceum indicates repeated backcrossing to the more abundant and/or genetically compatible parent, D. pavonaceum, with the hybrid plant becoming more like its recurrent parent over the generations. A related observation is that artificial interspecific crosses among 


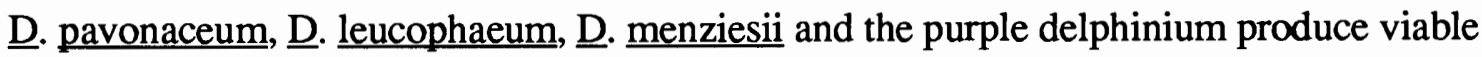
seeds (Goodrich 1985).

As shown in Figure 5, ‥ trolliifolium and the purple delphinium (potential hybrid) are consistently grouped together on the basis of chromosome measurements involving chromosomes 2 and 8 . Interestingly, $\underline{D}$. pavonaceum, the proposed backcross parent of the potential hybrid, differs from it in regards to the mean length of chromosome 2 and arm ratio of chromosome 8 . These data suggest that $\underline{D}$.trolliifolium is likely one of the parent species of the hybrid (if it is a hybrid) and that, contrary to the indications of plant

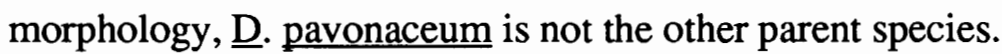

First metaphase and anaphase chromosome configurations of the purple delphinium are similar to those of the established Oregon species. Structural heterozygosity, a sign of hybridization, is absent. If the purple delphinium is a hybrid, the two parental genomes in its nuclei appear to be structurally similar at this level of investigation. Another possibility is that recurrent backcrossing with one parent has diluted the hybrid genome to the point where only chromosomes from the recurrent parent are present. Alternatively, it may not be a hybrid.

\section{REPRODUCTION}

\section{Comparison of Species}

Two general features contribute to impaired fertility: chromosome heterozygosity leading to segregational problems at meiosis and genetic differences. Microsporogenesis in these Oregon delphiniums is characterized by the formation of first division bivalents, balanced chromosome segregation and the formation of four haploid microspores. Meiotic failure is either uncommon or absent in the anthers of the purple delphinium. This reflects the situation in California where the natural, fertile hybrid, D. gypsophilum, also showed 
the expected number of bivalents and normal chromosome segregation (Lewis and Epling 1959).

Viable pollen grains are further indication of reproductive success. All three species

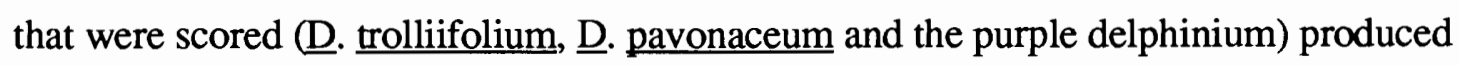

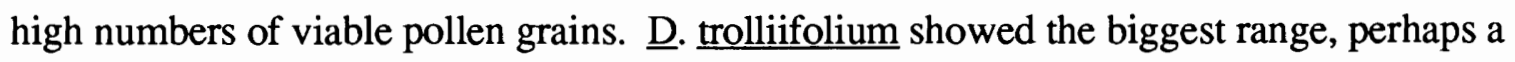
more accurate reflection, due to a larger sample, of the known variability of viable pollen in this genus. Lewis and Epling (1954) described a wide fertility range from high to very low among nine naturally occurring hybrids in California. Lewis and Epling (1959) noted a large range of pollen viability ( 25 to $70 \%$ ) within and among three northern California species. A full seed set for the California species, including interspecific hybrids, was usual. It was thus concluded that pollen is not a good indicator of fertility. However, the consistently high number of viable pollen in these Oregon species correlates with their high seed set and germination percentages and is perhaps a more accurate indication of fertility in these three groups. The development of pollen tubes from several pollen grains of each species is further indication of the reproductive success of these populations.

The proportion of viable seeds out of the total seed count indicates regenerative capability at a higher level of cellular organization than that of pollen. The data suggest that a range of about 60 to $90 \%$ viable seed production is typical of the species in this study. These results agree with a previous study of seed production in three of these species:

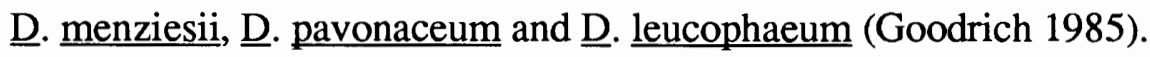

The majority of seeds of each of the Oregon species produced radicles when kept moist at a constant $6{ }^{\circ} \mathrm{C}$. This corresponds well to the abundance of viable pollen and seeds in these groups and confirms reproductive capacity in the purple delphinium as well. No percentages of germinated seeds are available for other species that germinated under similar conditions (Santana 1975). 
A previous study of two California species involved the exposure of seeds to ambient winter conditions (Lewis and Epling 1959) found that 57\% of D. hesperium and 55\% of D. recurvatum seeds germinated over the winter. When compared to the cold winter germination percentages of the present study, these results are similar to those of D. menziesii (52\%) and ‥ trolliifolium (42\%) but lower than D. pavonaceum (75\%), D. leucophaeum (90\%) and the purple delphinium (90\%).

Goodrich (1985) exposed seeds to ambient winter conditions and the percentages of germinated seeds were low: $\underline{\mathrm{D}}$. menziesii (3.6\%), purple delphinium (19.3\%), D. leucophaeum $(23 \%)$ and D. pavonaceum $(24.6 \%)$. This may be explained by the fact that only seedlings were counted. It is possible that far more seeds germinated than developed into seedlings, due to external factors such as mold and predation.

In the present study, differences in the response of $\underline{D}$. leucophaeum seeds to various germination conditions may be due to adaptations to a somewhat different and possibly more isolated habitat. The island plants from which seeds were collected were found in rocky, sandy soil. Their seeds produced fewer radicles at the optimum temperature of $6{ }^{\circ} \mathrm{C}$ than when exposed to a subfreezing winter, in contrast to seeds of the other species. Also, D. leucophaeum seeds germinated earlier than those of the other species and were the only ones (four seeds only) to germinate at $12^{\circ} \mathrm{C}$, which has been found to be too warm for these species.

Like $\underline{\text { D. leucophaeum, }} 90 \%$ of the seeds of the purple delphinium germinated during a sub-freezing winter, in contrast to $\underline{\mathrm{D}}$. pavonaceum, $\underline{\mathrm{D}}$. trolliifolium and $\underline{\mathrm{D}}$. menziesii. This different response may reflect a hybrid genotype that is better adapted to extreme conditions than the genotypes of its suggested parental species (‥ pavonaceum $\times \underline{\text { D. }}$. trolliifolium or D. menziesii. 
Germination Technique

Attempts to initiate seed germination in some species have led to various recommendations regarding proper treatment for maximum yield. The different temperatures suggested for obtaining maximum germination likely depend on the species in question. For example, Bewley and Black (1985) found that a high number of D. ambiguum seeds germinate at temperatures ranging from 5 to $15^{\circ} \mathrm{C}$ and a few seeds were found to germinate at $35^{\circ} \mathrm{C}$. Prior to germination, a two week chill at $6{ }^{\circ} \mathrm{C}$ is needed to break dormancy. Baskin and Caudle (1968) discovered that D. virescens germinates only at temperatures between 10 and $20^{\circ} \mathrm{C}$ and does not require pre-chilling. Legro (1961) found that $\underline{\mathrm{D}}$. cardinale, $\underline{\mathrm{D}}$. nudicaule, $\underline{\mathrm{D}}$. elatum and $\underline{\mathrm{D}}$. zalil germinate well at $11{ }^{\circ} \mathrm{C}$ with no prior chilling. Santana (1975) tried to germinate moist seeds at $25^{\circ} \mathrm{C}$ with no success until the seeds were moved to $8^{\circ} \mathrm{C}$, where they germinated two weeks later. His study of four species from northern California, including $\underline{D}$. trolliifolium, found that seeds require only two weeks at $8^{\circ} \mathrm{C}$ to produce radicles (Table XI).

Whether in the field or lab, the seeds of these Oregon delphiniums require an extended cool, wet period in order to germinate and there is no known way to speed up the process. This is within the average angiosperm requirement of 100 days at $5{ }^{\circ} \mathrm{C}$ (Raven et al. 1986). The optimum artificial conditions (wet storage for three months at $6{ }^{\circ} \mathrm{C}$ ) reflect the natural conditions of these species, the seeds of which remain dormant from late summer through early winter and then germinate in late winter and early spring. The results contrast with a previous statement that members of this genus are difficult to germinate artificially (Waser and Price 1985).

Comparisons between those seeds stored at $6^{\circ} \mathrm{C}$ and those placed in pots outdoors throughout the winter indicate that, not surprisingly, seed germination is higher under consistent artificial conditions than in the field. Of the four temperatures to which the seeds were exposed, a constant $6^{\circ} \mathrm{C}$ provided for maximum germination. Data suggest a 


\section{TABLE XI}

\section{RECOMMENDED ARTIFICIAL CONDITIONS FOR GERMINATING DELPHINIUM SEEDS}

\begin{tabular}{|c|c|c|c|c|}
\hline Species & Temp. ${ }^{1}$ & Period & Stratification & Source \\
\hline D. ambiguum & $5-15^{\circ} \mathrm{C}$ & no data & 2 weeks@ $6{ }^{\circ} \mathrm{C}$ & Bewley \& Black 1985 \\
\hline D. virescens & $10-20^{\circ} \mathrm{C}$ & no data & not required & Baskin \& Caudle 1968 \\
\hline 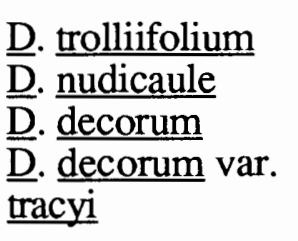 & $8^{\circ} \mathrm{C}$ & 2 weeks & not required & Santana 1975 \\
\hline $\begin{array}{l}\text { D. } \\
\text { D. cardinale } \\
\text { nudicaule } \\
\text { D. } \\
\text { D. } \\
\text { elatum } \\
\text { zalil }\end{array}$ & $11^{\circ} \mathrm{C}$ & $\begin{array}{c}2-3 \\
\text { months }\end{array}$ & not required & Legro 1961 \\
\hline D. ajacis & $12^{\circ} \mathrm{C}$ & 4 weeks & $1-4$ months & $\begin{array}{c}\text { Hartmann \& Kester } \\
1990\end{array}$ \\
\hline
\end{tabular}


preferred temperature range of 6 to $11^{\circ} \mathrm{C}$ for the species in this study. The optimum temperature is likely near the low end of this range. These conclusions compare favorably with those of some, but not all previous studies, possibly a reflection of the different natural environments of the species in question.

In agreement with a previous study (Goodrich 1985), certain pretreatments for breaking dormancy that are necessary for some seeds are not required by these Oregon species. This includes presoaking, pre-freezing, scarification or chemical treatment. The seeds are also unaffected by crowded conditions that may inhibit germination in other groups.

Interestingly, seeds of $\underline{D}$. menziesii and $\underline{D}$. pavonaceum that were left outside in the diurnal light of spring germinated readily, in contrast to previous evidence that darkness is preferred (Goodrich 1985).

Cold winter temperatures may be more favorable for germination than an unusually warm winter, even if temperatures drop below freezing for periods of up to to twelve days. It must be noted that the differences in germination percentages of the three species between the cold and warm winters may be coincidental and that factors other than winter temperatures are involved.

Delphinium seeds are known to remain dormant for one or two years until conditions are right for germination (Lewis and Epling 1959). The failure of seeds to germinate at higher temperatures can be interpreted as an adaptation which delays germination until temperature and moisture are favorable for seedling development.

The capacity for artificial germination throughout the year provides a source of fresh mitotic tissues for cytogenetic and other studies that can be available on demand. By planning ahead three months, the desired amount of seeds can be set up with a guarantee of high numbers of radicles. Also, the dry storage life (at $6^{\circ} \mathrm{C}$ ) of the seeds is at least 2.5 years and likely longer, removing the need to return each season to the field for more 
collections. It is possible that these species could be frozen, stored indefinitely and later carefully thawed for germination, as was $\underline{\mathrm{D}}$. exaltatum, a rare Ohio species (Woolf 1990).

Baskin and Caudle (1968) reported a drop in percent seed germination of $\underline{D}$. virescens with increased time in storage. Storage conditions were not given. In the case of these Oregon delphiniums, no decrease in percent germination occurred for seeds stored at $6{ }^{\circ} \mathrm{C}$ for up to 2.5 years.

The collection method ensures a low impact on plant populations. A mature plant produces from 180 to 450 seeds per season ( 15 seeds/follicle, 3 follicles/flower, 4 - 10 flowers/plant), depending on the species. This is a conservative estimate. It takes the seeds of only one flower of a plant and a few plants in a population to provide thousands of seed radicles, given the potentially high rate of germination.

Other sources of dividing cells are less reliable. Although mitotic cells were obtained from tissues such as shoot apices, leaf meristems and immature flower buds, the low mitotic index and marginal quality of the cells designate these sources as secondary alternatives when seeds are unavailable.

\section{TISSUE CULTURE}

In vitro culture of plant tissues provides a means of maintaining a supply of mitotic cells indefinitely for the purpose of chromosome study and also may contribute through plant regeneration to the recovery of endangered species. However, the growth of isolated plant cells or tissues in artificial medium often induces genetic variability that is frequently, but not always reflected in chromosome abnormalities. Gould (1986) found that at least $10 \%$ of the cells of most plants regenerated in vitro are karyologically variable and that callus and suspension cultures, which are largely disorganized groups of undifferentiated cells, contain consistently more karyotype abnormalities than regenerated plants. According to Phillips and Wang (1984), cytogenetic abnormalities that occur in vitro 
include changes in ploidy, various aneuploidies, multipolar mitoses, duplications, deletions, dicentric chromosomes, isochromosomes, translocations and inversions. Sunderland (1977) concluded that these changes are due to spindle malfunction, repeated DNA replication without cell division, and chromosome breakage.

Although the fundamental mechanisms of chromosome mutations are unknown, several factors, either natural or artificial, are involved. The genotype of the original plant is of major importance to genetic stability in culture; species and even varieties within a species may respond differently to the same culture conditions (Phillips and Wang 1984). The age, type and degree of cell organization of the donor tissue affect the outcome of culture, as well as variations in its genotype and karyotype. The rate of cell division and time spent proliferating in culture are also important. Once chromosomally abnormal cells appear, their frequency increases rapidly with time (Bayliss 1980). Plants in culture are largely heterotrophic; sugars, vitamins and inorganic compounds are required along with an exogenous supply of hormones. In many cases, chromosome abnormalities are the result of the culture environment and do not originate in the source tissue (Kumar and Walton 1992). For example, Gould (1986) showed that the auxin 2,4-dichlorophenoxyacetic acid increases the numbers of chromosomally abnormal cells in culture, most likely due to the rapid, disorganized growth that it induces. He concluded that mitotic integrity depends to a certain degree on the level of tissue organization.

In spite of the vast record of abnormalities, members of some genera are stable with no visible chromosomal mutations after as long as one year in culture (e.g., Crepis, Haplopappus, Daucus) (Sunderland 1977). Phillips and Wang (1984) found that some regenerated Allium species are also known to be chromosomally consistent in culture.

Given the factors influencing genetic stability in vitro, several ways to minimize chromosome change have been suggested. Apical meristems give rise to germline cells which require the presence of two factors that help ensure genetic stability for future 
generations: the control of DNA replication to prevent polyploidy and continuous cell divisions that prevent the accumulation of cells with chromosomal structural changes that, in turn, adversely affect cell division (D'Amato 1977). The best source tissue for culture is therefore apical meristem, the younger the better.

An alternative to the use of apical meristems is the induction of growth from organized tissues, for example organs or entire plants. Although genetically stable plants have been successfully regenerated from young calluses (Kumar and Walton 1992) it is generally considered safer to obtain organized tissues directly from the explants and bypass the disorganized, undifferentiated callus stage altogether (Gould 1986). Frequent subculturing to minimize the accumulation of aberrant cells is also recommended (Bayliss 1980).

Results of extensive in vitro culturing of the Oregon delphiniums indicate that further experimentation is necessary before conclusions regarding their culturability can be made. The many factors influencing genetic integrity and plant regeneration provide a wealth of opportunity as well as potential errors for the culture enthusiast.

The predominance of calluses in the Oregon Delphinium cultures may be a sign of inappropriate hormone concentrations and ratios and/or missing nutrients. Further experimentation with media, light, timing of subcultures and temperature may result in a protocol which inhibits callus formation and promotes actively dividing cells for chromosome study.

The emphasis here is on developing a system for maintaining a dependable source of representative chromosomes. The current production of mixoploid tissues from various types of Delphinium explants and the predominance of calluses suggests that in vitro culturing is not a preferable alternative to collecting seeds from the field. However, the concurrent development of roots from organized tissues and callus that contain diploid metaphase nuclei is evidence of the potential of in vitro culturing as a means of obtaining cytogenetically useful material. 
These species show qualified potential for in vitro plant regeneration. The development of rootless stems with leaves and branches is a positive response to culture conditions that, with modification, might produce entire plants.

Ranunculus scleratus (Ranunculaceae) has been regenerated in vitro. In an effort to test whether or not other members of Ranunculaceae share this potential, Nataraja (1971) subjected flower buds and anthers from three genera, including Delphinium (D. brunionanum), to various culture media. Both anthers and flower buds produced calluses from which roots developed. No shoot buds or other organs developed. These results are similar to those of the Oregon species. However, a recent report of the successful regeneration of an entire delphinium plant in the Netherlands is cause for anticipation of some degree of success with delphiniums from Oregon (McRae, personal communication 1990). 


\section{CONCLUSION}

This study of populations of Delphinium in Oregon has lead to the following conclusions:

1. The unbanded karyotypes of the Oregon delphiniums are identical in number and appear to be morphologically similar. These observations suggest that there has been little chromosome evolution or that it has been parallel in nature.

2. Statistical analyses of chromosome measurements show significant differences among the Oregon species and indicate that $\underline{D}$. trolliifolium and the purple delphinium are more closely related to each other than they are to the other three species. The data also suggest that $\underline{\mathrm{D}}$. trolliifolium may be one of the parent species of the purple delphinium,

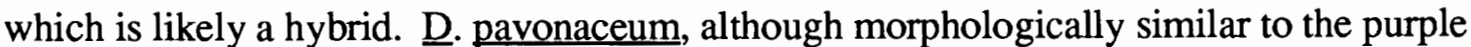
delphinium is likely not its other parent species.

3. Differences in karyotype morphology between the Oregon species and those of California or more distant are evidence of chromosome evolution within the genus.

4. The apparent absence of structural heterozygosity in the meiotic chromosomes of the four established species suggests that either no introgression has occurred or that the chromosomes of these species are structurally, if not genetically, similar. The absence of structural heterozygosity in the purple delphinium is evidence that the karyotypes of the two parent species are structurally similar. Another possibility is that recurrent backcrossing with one parent has diluted the hybrid genome to the point where only chromosomes from the recurrent parent are present. Alternatively, it may not be a hybrid.

5. Successful meiosis is reflected by consistently high levels of seed production and germination in these delphiniums. If the purple delphinium is indeed a hybrid, its reproductive potential is not adversely affected by its hybrid origin. 
6. Extensive experimentation with tissue culture produced mostly calluses, some roots and a few odd structures. Cell divisions occurred in roots and calluses but at much lower numbers than in germinating seed radicles. Calluses contained largely polyploid cells and are not dependable sources of representative genomes. Roots grown in vitro are potential sources of diploid chromosome preparations. The development of plant structures from Delphinium tissues indicates that in vitro culturing has the potential to be a means of regenerating whole plants.

7. A single plant can produce hundreds of seeds, a few of which can be collected with negligible impact on plant populations. Successful germination and subsequent development of seedlings into mature plants provides either a source of mitotic tissues for cytogenetics or new plants for possible reintroduction into a favorable habitat.

\section{AREAS FOR FUTURE STUDY}

The orcein stained karyotypes of the Oregon Delphiniums are morphologically similar which may or may not be an accurate reflection of chromosome similarity and/or genetic content. Also, four orcein stained chromosomes of each genome are indistinguishable. Greater chromosome resolution is needed in order to clarify chromosome identification and evolution, species relationships and hybrid origin in these Delphinium species.

Chromosome banding, particularly C-banding (constitutive heterochromatin), has been useful in addressing the above questions in other plant genera. Potentially, C-bands are taxonomically informative in that interspecific C-band patterns may differ (Fukuda 1984). Many attempts at $\mathrm{C}$-banding the chromosomes of the Oregon delphiniums during the course of this project were unsuccessful. This is possibly due to the sensitive nature of the techniques involved in banding and not necessarily due to factors that are inherent in these species. Attempts by those more experienced in plant banding techniques might prove successful. Other banding techniques may also be informative. 
A precise account of satellite number and position of the Oregon Delphiniums was not possible due to several factors. Some factors could be eliminated by silver staining nucleolar organizing regions which lie adjacent to secondary constrictions in most species (Reed and Burns 1987). This procedure is not entirely dependable since the stain only marks transcriptionally active NORs, a feature that may vary among individuals of a species (Babu and Verma 1987). Also, silver stain would not identify homologues. However, localization of NORs does increase the accuracy of satellite counts and is useful when combined with other observations.

The use of this selective silver stain could contribute to hybrid analysis. Fominaya et al. (1988) reported that nucleolar competition in a hybrid between the NORs of its two parent species can result in the suppression of transcriptional activity of one of the NORs. A consistently lower number of satellites or a decrease in the number of stained NORs is evidence of this phenomenon and could help verify a hybrid if backcrossing has not eliminated all or part of one species' genome, the source of nucleolar competition.

At the molecular level, allozyme studies have been useful for clarifying relationships among groups of species (Guerrant, personal communication 1992). It is especially useful in combination with cytogenetics, morphology and geographical distribution. Allozyme studies can also identify parental genes in a hybrid. The purple delphinum of Oregon, proposed to be a hybrid, is a likely subject for such an investigation.

As suggested earlier, continued experimentation with in vitro cultivation of Delphinium tissues could provide a means of obtaining dependable experimental material or, more importantly in the case of rare species, a source of reintroducible plants. 


\section{SELECTED REFERENCES}

Al-Kelidar, R. K., \& A. J. Richards (1981). Chromosomal indications of evolutionary trends in the genus Delphinium L. Ctyologia, 46, 623-633.

Alexander, M. P. (1969). Differential staining of aborted and nonaborted pollen. Stain Technology, 44(3), 117-122.

Babu, A., \& R. Verma (1987). Chromosome structure: euchromatin and heterochromatin. International Review of Cytology, 108, 1-60.

Basak, S. L., \& H. K. Jain (1964). The interchromosome distribution of chiasmata in interchange heterozygotes of Delphinium. Heredity, 19(1), 53-61.

Baskin, J. M., \& C. Caudle (1968). Germination and dormancy in cedar glade plants. II. Delphinium virescens. Journal of Tennessee Academy of Sciences, 43(4), 115-116.

Bayliss, M. W. (1980). Chromosomal variation in culture. In I. K. Vasil (Eds.), International Review of Cytology Supplement IIA (pp. 113-144). New York: Academic Press.

Bewley, J. D., \& M. Black (1985). Seeds: Physiology of Development and Germination. New York: Plenum Press.

D'Amato, F. (1977). Cytogenetics of differentiation in tissue and cell cultures. In J. Reinert \& Y. P. S. Bajaj (Eds.), Plant Cell, Tissue and Organ Culture (pp. 343-357). Springer-Verlag: New York.

Darlington, C. D., \& L. F. La Cour (1976). The Handling of Chromosomes (6 ed.). New York: John Wiley \& Sons, Inc.

Dyer, A. F. (1979). Investigating Chromosomes (1 ed.). New York: John Wiley \& Sons, Inc.

Epling, C., \& H. Lewis (1952). Increase of the adaptive range of the genus Delphinium. Evolution, $\underline{6}, 253-267$.

Ewan, J. (1945). A synopsis of the North American species of Delphinium. University of Colorado Studies. Series D, 2(2), 55-244.

Fominaya, A., et al. (1988). C-banding and nucleolar activity of tetraploid Avena species. Genome(33), 633-638.

Fukuda, I. (1984). Chromosome banding and biosystematics. In W. E. Grant (Eds.), Plant Biosystematics (pp. 97-116). New York: Academic Press. 
Goodrich, G. (1985) Rare and common species of Delphinium in Oregon and Western Washington: a systematic and ecological study. Master of Science, Oregon State University.

Gould, A. R. (1986). Factors controlling generation of variability in Vitro. In I. K. Vasil (Eds.), Cell Culture and Somatic Cell Genetics of Plants (pp. 549-567). New York: Academic Press.

Guerrant, E. O. (1982). Neotenic evolution of Delphinium nudicaule (Ranunculaceae): a

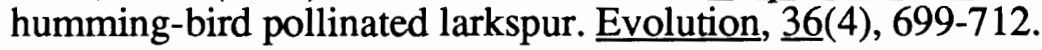

Hartmann, H. T., \& D. E. Kester (1990). Plant Propagation; Principles and Practices (5 ed.). Englewood Cliffs: Prentice-Hall.

Heslop-Harrison, J. S., et al. (1988). The absence of the somatic association of centromeres of homologous centromeres of homologous chromosomes in grass mitotic metaphases. Chromosoma, 96, 119-131.

Hitchcock, C. L., \& A. Cronquist (1990). Flora of the Pacific Northwest (7 ed.). Seattle: University of WashingtonPress.

Hsiao, C. (1986). Karyotype analysis and genome relationships of 22 diploid species in the tribe Triticaceae. Canadian Journal of Genetics and Cytology, 28, 109-120.

Jain, H. K., \& S. L. Basak (1963). Genetic interpretation of chiasmata in Delphinium. Genetics, $\underline{48}, 329-339$.

Jamilena, M. (1990). Variation in the heterochromatin and nucleolar organizing regions of Allium subvillosum L. (Liliaceae). Genome, $\underline{33}, 779-784$.

Kumar, P. S., \& P. D. Walton (1992). Plant regeneration and chromosome instability in tissue culture of Elymus canadensis $\times \underline{E}$. trachycaulus $F_{1}$ hybrid. Genome, $\underline{35}, 88-91$.

Kyte, L. (1987). Plants From Test Tubes (1 ed.). Portland: Timber Press.

Lawrence, W. J. C. (1935). The Origin of New Forms in Delphinium. Genetica, 18, 109115.

Legro, R. A. H. (1961). Species hybrids in Delphinium. Euphytica, 10(1), 1-120.

Levan, A., et al. (1964). Nomenclature for Centromeric Position on Chromosomes. Hereditas, 52, 201-220.

Lewis, H. (1946). Abstract. American Journal of Botany, 33, 26 a.

Lewis, H., \& C. Epling (1954). A taxonomic study of California delphiniums. Brittonia, $\underline{8}(1), 1-22$.

Lewis, H., \& C. Epling (1959). Delphinium gypsophilum, a diploid species of hybrid origin. Evolution, 13, 511-525. 
Lewis, H., et al. (1951). Chromosome numbers of Californian delphiniums and their geographical occurrence. Annals of the Missouri Botanical Garden, 38, 101-117.

Mehlquist, G. A. L., et al. (1943). Colchicine induced tetraploidy in Delphinium cardinale. Journal of Heredity, 34, 187-192.

Morais, L., et al. (1991). Differential effects of colchicine in genotypes with one or more haploid sets. Cytologia, $\underline{56}(2), 157-164$.

Nataraja, K. (1971). Morphogenic variations in callus cultures derived from floral buds and anthers of some members of Ranunculaceae. Phytomorphology, 21(4), 290-295.

Oregon Natural Heritage Program. 1991. Rare, Threatened and Endangered Plants and Animals of Oregon. Oregon Natural Heritage Program, Portland Oregon. 64 p.

Phillips, R. L., \& A. S. Wang (1984). Chromosome analysis. In I. K. Vasil (Eds.), Cell Culture and Somatic Cell Genetics of Plants New York: Academic Press.

Raven, P. H., et al. (1986). Biology of Plants (4 ed.). New York: Worth Publishers, Inc.

Rayburn, A. L. (1990). Genome size variation in southwestern United States Indian maize adapted to various altitudes. Evolutionary Trends in Plants, 4(1), 53-57.

Reed, S., \& J. Burns (1987). The nucleolus organizer chromosomes of Nicotiana tabacum. The Journal of Heredity, $\underline{78}, 400-401$.

Santana, D. (1975) Analysis of a natural Delphinium (Ranunculaceae) hybrid swarm. Master of Science, Humboldt State University.

Sigma, C. C. (1990). Plant Cell Culture. In USA: Sigma Chemical Company.

Stebbins, G. L. (1971). Chromosomal Evolution in Higher Plants. Menlo Park: AddisonWesley Publishing Co.

Sunderland, N. (1977). Nuclear Cytology. In H. E. Street (Eds.), Plant Tissue and Cell Culture (pp. 177-205). London: Blackwell Scientific Publications.

Suzuki, D., et al. (1989). An Introduction to Genetic Analysis (4 ed.). New York: W. H. Freeman and Company.

Swanson, C. P., et al. (1981). Cytogenetics: The Chromosome in Division, Inheritance and Evolution ( 2 ed.). Englewood Cliffs: Prentice Hall, Inc.

Tjebbes, K. (1927). The chromosomes of three Delphinium species. Hereditas, 10, 160164.

Warnock, M. J. (1987). Vicariant distribution of two Delphinium species in southeastern United States. Botanical Gazette, 148(1), 90-95.

Waser, N. M., \& M. V. Price (1985). Reciprocal transplant experiments with Delphinium nelsonii (Ranunculaceae): evidence for local adaptation. American Journal of Botany, $\underline{72}(11), 1726-1732$. 
White, P. (1963). The Cultivation of Animal and Plant Cells (2 ed.).

New York: Ronald Press Company.

Wiemarck, A. (1981). Heterochromatin polymorphism in the rye karyotype as detected by the Giemsa C-banding technique. Hereditas, 79(1), 293-300.

Woolf, N. B. (1990). Biotechnologies sow seeds for the future. Bioscience, 40 (5), 346348. 
APPENDIX A

CHROMOSOME NOMENCLATURE 


\section{CHROMOSOME DESIGNATON AS BASED ON CENTROMERE LOCATION}

\begin{tabular}{lccc}
\hline Centromeric Position & Arm Ratio & Chromosome Designation & Symbol \\
\hline median (single point) & 1.0 & metacentric & $\mathrm{M}$ \\
median region & $1.0-1.7$ & metacentric & $\mathrm{m}$ \\
submedian & $1.7-3.0$ & submetacentric & $\mathrm{sm}$ \\
subterminal & $3.0-7.0$ & subtelocentric & $\mathrm{st}$ \\
terminal region & $7.0+$ & acrocentric & $\mathrm{a}$ \\
terminal (single point) & infinity & telocentric & $\mathrm{T}$ \\
\hline Adapted from Levan 1964,217 & & &
\end{tabular}

Adapted from Levan 1964, 217. 
APPENDIX B

MEDIA CONTENTS FOR TISSUE CULTURE 


\section{BASIC MEDIUM FOR 500 ML OF CULTURE MEDIA}

\begin{tabular}{lc}
\hline ingredients & amount for $1 \mathrm{~L}$ solution \\
\hline $0.44 \%$ medium $^{1}$ & $4.4 \mathrm{~g}$ \\
$3.0 \%$ sucrose & $30.0 \mathrm{~g}$ \\
$0.0 \%$ agar & $15.0 \mathrm{~g}$ \\
\hline
\end{tabular}

1 basic medium of Murashige and Skoog containing macro- and micronutrients and vitamins (Sigma Chemical Company, St. Louis, Missouri 1990)

HORMONE RATIOS AND THEIR CORRESPONDING CONCENTRATION IN STOCK SOLUTION FOR 1 LITER OF CULTURE MEDIA

\begin{tabular}{|c|c|c|}
\hline $\begin{array}{l}\text { hormone ratio } \\
\text { NAA : BA }\end{array}$ & $\begin{array}{c}\text { stock solution }(\mathrm{mg} / \mathrm{ml}) \\
\text { NAA : BA }\end{array}$ & $\mathrm{ml}$ of stock per $1 \mathrm{~L} \mathrm{dH_{2 } \mathrm { O }}$ \\
\hline $1.00: 1.00$ & $1.00: 1.00$ & $: 1$ \\
\hline $1.00: 0.00$ & $1.00: 0.00$ & 0 \\
\hline $0.00: 1.00$ & $0.00:$ & 1 \\
\hline$: 0.50$ & $1.00: 0.10$ & 5 \\
\hline$: 3.00$ & $0.10: 1.00$ & $5: 3$ \\
\hline
\end{tabular}

Note: NAA $=1$-napthaleneacetic acid (auxin)

$\mathrm{BA}=$ benzyladenine (cytokinin) 
APPENDIX C

SURVEY OF THE LITERATURE 
GENERAL SURVEY OF DELPHINIUM CHROMOSOME STUDIES

\begin{tabular}{|c|c|c|c|}
\hline Location & Species & $2 \mathrm{~N}$ & Reference \\
\hline California & D. andersonii & 16 & Lewis 1951 \\
\hline California & D. californicum & 16 & Lewis 1951 \\
\hline California & D. cardinale* & 16 & Mehlquist 1943 \\
\hline California & D. decorum & 16 & Lewis 1951 \\
\hline California & D. glaucum* & 16 & Lewis 1951 \\
\hline California & D. gracilentum & 16 & Lewis 1951 \\
\hline California & D. gypsophilum* & 16,32 & Lewis 1951 \\
\hline California & D. hanseni* & 16,32 & Lewis 1951 \\
\hline California & D. hesperium* & 16 & Lewis 1951 \\
\hline California & D. hesperium $\mathrm{f}$. pallescens & 16 & Lewis 1951 \\
\hline California & D. hesperium var. cuyamacae & 16 & Lewis 1951 \\
\hline California & D. inopinum & 16 & Lewis 1951 \\
\hline California & D. nudicaule & 16 & Tjebbes 1927 \\
\hline California & D. nutallianum & 16 & Lewis 1951 \\
\hline California & D. parishii* & 16 & Lewis 1951 \\
\hline Califormia & D. parryi* & 16 & Lewis 1951 \\
\hline California & D. parryi ssp. seditiosum & 16 & Lewis 1951 \\
\hline California & D. parryi var. blochmanae & 16 & Lewis 1951 \\
\hline California & D. patens & 16 & Lewis 1951 \\
\hline California & D. polycladon & 16 & Lewis 1951 \\
\hline California & D. purpussii & 16 & Lewis 1951 \\
\hline California & D. recurvatum $*$ & 16 & Lewis 1951 \\
\hline
\end{tabular}


GENERAL SURVEY OF DELPHINIUM

CHROMOSOME STUDIES

(continued)

\begin{tabular}{|c|c|c|c|}
\hline Location & Species & $2 \mathrm{~N}$ & Reference \\
\hline California & D. trolliifolium & 16 & Lewis 1951 \\
\hline California & D. uliginosum & 16 & Lewis 1951 \\
\hline California & D. umbraculorum & 16 & Lewis 1951 \\
\hline California & D. variegatum* & 16,32 & Lewis 1951 \\
\hline California & D. ajacis & 16 & Lewis 1951 \\
\hline Caucasus & D. caucasicum* & 32 & Al-Kelidar 1981 \\
\hline China & D. bullyanum* & 32 & Al-Kelidar 1981 \\
\hline Eurasia & D. elatum & 32 & Lawrence 1935 \\
\hline Himalayas & D. cashmerianum* & 32 & Al-Kelidar 1981 \\
\hline Himalayas & D. denudatum* & 32 & Al-Kelidar 1981 \\
\hline North America & D. geyeri* & 32 & Al-Kelidar 1981 \\
\hline North America & D. leiocarpum* & 32 & Al-Kelidar \\
\hline Pakistan & D. zalil & 16 & Legro 1961 \\
\hline Russia & D. corymbosum* & 32 & Al-Kelidar 1981 \\
\hline Russia & D. formosum* & 32 & Al-Kelidar 1981 \\
\hline Russia & D. triste* & 32 & Al-Kelidar 1981 \\
\hline not given & D. azureum & 32 & Lawrence 1935 \\
\hline not given & D. belladonna & 48 & Legro 1961 \\
\hline not given & D. brunionanum* & 16,32 & Lawrence 1935 \\
\hline not given & D. cardiopetalum & 16 & Tjebbes 1927 \\
\hline not given & D. chinense & 16 & Lawrence 1935 \\
\hline
\end{tabular}


GENERAL SURVEY OF DELPHINIUM

CHROMOSOME STUDIES

(continued)

\begin{tabular}{|c|c|c|c|}
\hline Location & Species & $2 \mathrm{~N}$ & Reference \\
\hline not given & D. delavayi* & 16 & Al-Kelidar 1981 \\
\hline not given & D. fissum & 32 & Lawrence 1935 \\
\hline not given & D. grandiflorum & 16 & Lawrence 1935 \\
\hline not given & D. hybridum & 32 & Lawrence 1935 \\
\hline not given & D. lamartinii & 48 & Legro 1961 \\
\hline not given & D. moerheimii & 24 & Legro 1961 \\
\hline not given & D. ruysii & 32 & Legro 1961 \\
\hline not given & D. staphysagria* & 16,32 & Lawrence 1935 \\
\hline not given & D. tatsiense & 16 & Lawrence \\
\hline not given & D. truncatum & 32 & Lawrence 1935 \\
\hline
\end{tabular}

Note: Location may not be the original or the only location and "species" includes some cultivars.

* chromosome morphology also studied 